\title{
10. ja 11. klassi õpilaste bioloogia-alase kirjaoskuse kognitiivsete komponentide hindamine
}

\author{
Aveliis Post $^{\mathrm{a} 1}$, Helin Semilarski ${ }^{\mathrm{a}}$, Anne Laius ${ }^{\mathrm{a}}$ \\ ${ }^{a}$ Tartu Ülikooli loodusteadusliku hariduse keskus
}

\begin{abstract}
Annotatsioon
Eesti põhikooli õpilaste loodusainete tulemused on PISA 2015 andmetel maailmas tipptasemel, kuid need ei kajastu gümnaasiumilõpetajatest kõrgkooli sisseastujate tasemes. Samas on ühiskonnas vajadus noorte järele, kes kasutavad loodusteaduslikke teadmisi probleemide lahendamiseks ning igapäevaeluliste otsuste tegemiseks ja põhjendamiseks. Uurimuse eesmärk on mõõta interdistsiplinaarse kontekstipõhise instrumendi abil 10. ja 11. klassi õpilaste bioloogia-alast kirjaoskust, võttes aluseks neli uuringuks välja valitud kognitiivset komponenti, et saada ülevaade gümnaasiumiõpilaste bioloogia-alase kirjaoskuse tähtsaimate kognitiivsete komponentide hetkeolukorrast. Tulemused näitavad, et kolm mõõdetud kognitiivset komponenti (probleemide lahendamise oskus, otsuse tegemise ja põhjendamise oskus ning loodusteadusliku loova mõtlemise voolavus) on keskmisel või madalal saavutustasemel ning üks komponent (bioloogia-alaste teadmiste reprodutseerimine) kõrgel saavutustasemel. Uuringu tulemusena selgub, et õpilaste bioloogiaalase kirjaoskuse kognitiivsetes komponentides esineb soolisi erinevusi nii 10. kui ka 11. klassi õpilastel, kuid tüdrukute natuke paremad tulemused kõikide ülesannete lahendamisel ei ole statistiliselt ega ka sisuliselt olulised. Uuring näitab, et gümnaasiumiõpilastel on bioloogiahariduses vaja rohkem tähelepanu pöörata probleemide lahendamise, otsuste tegemise ja põhjendamise oskuste ning loovuse arendamisele.
\end{abstract}

Võtmesõnad: bioloogia-alane kirjaoskus, kontekstipõhine hindamine, gümnaasiumiõpilased

Loodusteadusliku hariduse keskus, Tartu Ülikool, Vanemuise 46, 51014 Tartu; aveliis.post@ut.ee 


\section{Sissejuhatus}

Tänapäeva ühiskond seisab probleemi ees, kuidas õpetada noori, kes oleksid valmis töötama töökohtadel, mida veel ei eksisteeri, ja kuidas õpetada praeguseid ópilasi nii, et nad saaksid hakkama pidevalt muutuvas maailmas. Seega, peale aineteadmiste omandamise koolis on olulisel kohal ka oskus kasutada neid teadmisi probleemide lahendamisel ja otsuste tegemisel, samuti peetakse oluliseks oskust teha koostööd ning mõelda loovalt (Greiff \& Neubert, 2014; Schleicher, 2014).

Rahvusvaheliste PISA uuringute andmetel (PISA, 2006, 2015) on Eesti põhikooliõpilased loodusteaduslikus kirjaoskuses kõrgel kohal maailmas ning parimad Euroopas, kuid kõrgkoolide õppejõud ei ole rahul kõrgkooli sisseastujate (gümnaasiumilõpetajate) loodus- ja reaalainete tasemega (Kübarsepp, 2006; Teichmann \& Kübarsepp, 2008) ning ühiskonna huvigrupid ei näe loodus- ja reaalainete hariduse märkimisväärset positiivset mõju Eesti majandusele (Majandus- ja Kommunikatsiooniministeerium, 2013). Aineteadmiste rakendamise oskust probleemide looval lahendamisel ning otsuste tegemisel ja põhjendamisel on vaja arendada loodusainete tundides, sh bioloogiatundides, kogu gümnaasiumiõpingute vältel, et valmistada ópilasi ette seisma silmitsi uudsete ja keeruliste olukordadega, millel ei ole ühest ja lihtsat lahendust. Need eesmärgid on sõnastatud ka 2011. aastal kehtima hakanud gümnaasiumi riiklikus õppekavas (2011).

Ühiskonna huvigruppide (teadlaste, tööandjate, õpetajate jt) ootused gümnaasiumilõpetajate teadmiste ja oskuste suhtes peegeldavad vajadust selliste inimeste järele, kes oleksid vajaduse korral võimelised teadmisi ja oskusi nii tööl kui ka kodus rakendama, töötama meeskonnas ning jõudma võimalikult heade tulemusteni. Samas ei ole hinnang hetkeolukorrale rahuldav - eri huvigruppide hinnangul ei suuda õpilased gümnaasiumiaastate jooksul omandatud teadmisi ja oskusi piisavalt hästi rakendada, mistõttu nad vajaks pikaajalist lisakoolitust, et töötada, edasi õppida või oma rollile vastavaid igapäevaseid ülesandeid täita (Laius, Post, \& Rannikmäe, 2015a; Laius, Valdmann, \& Rannikmäe, 2015b).

Uurimustes on leitud, et õpilaste oskuste (sh probleemide lahendamise, otsuste tegemise, põhjendamise ja loova mõtlemise oskuste) tõhusaks arenemiseks ja arendamiseks on vaja rakendada aineõppes sotsiaalse suunitlusega loodusteaduslikke õppematerjale ja -meetodeid. Kontekstipõhiste situatsioonide lahendamise kaudu on võimalik aines omandatud teadmisi rakendada ning luua seoseid igapäevaeluga, muutes teadmised ópilastele relevantsemaks (Eastwood, Sadler, Sherwood, \& Schlegel, 2013; Greiff \& Neubert, 2014). 
Siinse uurimuse eesmärk on keskenduda bioloogiaharidusele ja seetõttu on loodusteadusliku kirjaoskuse kui kõiki loodusaineid (füüsikat, keemiat, bioloogiat ja maateadust) hõlmavat mõistet kitsendatud, käsitledes seda bioloogia-alase kirjaoskusena. Uue põlvkonna kolmedimensioonilise loodusainete õpetamise standardi (Quinn, Schweingruber, \& Keller, 2011) kohaselt on kõikidel loodusainetel ühised teaduslikud meetodid ja arusaamad loodusteaduslikest põhiprotsessidest ning nähtustest, kuid neid eristavad üksteisest ainespetsiifilised eriteadmised. Seetõttu kasutatakse siinses uurimuses bioloogia-alase kirjaoskuse mõistet, mis märgib inimese võimet kasutada bioloogia-alaseid teadmisi ja oskusi loovaks probleemide lahendamiseks ja põhjendatud otsuste tegemiseks (Demastes \& Wandersee, 1992; Uno \& Bybee, 1994). Heal tasemel bioloogia-alane kirjaoskus annab inimesele võimaluse paremini mõista ja selgitada endaga ning enda ümber toimuvaid protsesse (ibid.).

Bioloogia-alane kirjaoskus on kompleksne mõiste, mis sisaldab aineteadmisi, oskusi, hoiakuid ja väärtushinnanguid. Praegusel juhul käsitletakse vaid mõtlemise ja info töötlemisega seotud ehk kognitiivseid komponente, mida nimetatakse edaspidises tekstis lühidalt komponentideks.

Laktoositalumatuse kui ühiskonnas aktuaalse terviseprobleemi puhul saab hinnata bioloogia-alast kirjaoskust nelja komponendi kaudu, milleks on aineteadmised (I komponent), probleemide lahendamise oskus (II komponent), otsuste tegemise ja põhjendamise oskus (III komponent) ning loodusteadusliku loova mõtlemise voolavus (ingl fluency) ehk loodusteaduslik loovus (IV komponent). Nende vajalikkust on rõhutanud nii ühiskonna sihtrühmad (Laius et al., 2015a; Laius, Post, \& Rannikmäe, 2016), gümnaasiumi riiklik õppekava (2011) kui ka rahvusvahelised loodusteadusliku ja tehnoloogia-alase kirjaoskuse uuringud (OECD, 2014; PISA, 2006, 2015).

Uurimuse eesmärk on hinnata interdistsiplinaarse kontekstipõhise instrumendi abil gümnaasiumiastme bioloogia-alase kirjaoskuse kognitiivseid komponente ning võrrelda 10. ja 11. klassi õpilaste tulemusi ning välja selgitada soolised erinevused, et saada teaduspõhine ülevaade hetkeolukorrast ja kavandada selle põhjal edaspidiseid tegevusi gümnaasiumi bioloogiahariduse ajakohastamiseks. Selleks korraldati kaks uuringut: 10. klassi alguses läbi viidud uuringuga selgitati välja gümnaasiumiõpilaste bioloogia-alane kirjaoskus õpingute alguses, lähtudes eelnimetatud neljast komponendist, ning 11. klassi kevadel läbi viidud uuringuga uuriti erinevusi, mis on toimunud vaatlusaluste õpilaste bioloogia-alase kirjaoskuse komponentides kahe õppeaasta vältel, mil nad on bioloogiat õppinud. Eritähelepanu pöörati sugudevahelistele erinevustele, mille uurimine 
moodustab sageli osa bioloogia-alastest haridusuuringutest, sest on leitud, et eri õppeainete puhul sõltuvad tulemused suuresti soost (PISA, 2006, 2015).

Koostatud kontekstipõhise testiga saadud esmaseid tulemusi, mis põhinevad kirjeldaval statistikal, tutvustati rahvusvahelisel konverentsil „Global conference on contemporary issues in education" (Laius et al., 2015b). Uurimistulemuste põhjalikumaks analüüsimiseks on selles artiklis sõnastatud järgmised uurimisküsimused.

1. Millised on gümnaasiumiõpilaste bioloogia-alase kirjaoskuse kognitiivsed komponendid (aineteadmised, probleemide lahendamise oskus, otsuste tegemise ja põhjendamise oskus ning loovus)?

2. Millised erinevused on 10. ja 11. klassi õpilaste bioloogia-alase kirjaoskuse kognitiivsetes komponentides (aineteadmised, probleemide lahendamise oskus, otsuste tegemise ja põhjendamise oskus ning loovus)?

3. Millised on soolised erinevused bioloogia-alases kirjaoskuses, võttes arvesse nelja komponenti: aineteadmisi, probleemide lahendamise oskust, otsuste tegemise ja põhjendamise ning loova mõtlemise oskust?

\section{Kirjanduse ülevaade}

Me elame pidevalt keerukamaks muutuvas ühiskonnas, mis seab inimestele üha uusi ülesandeid. Globaliseerumine, tehnoloogia ja ärimudeli arenemine ning muutunud ootused töötajate suhtes on viimaste aastakümnete jooksul põhjustanud töö ja tööjõu iseloomu muutuse (Beier, 2014; Lavonen et al., 2008). Ühiskond eeldab head suhtlemis- ja koostööoskust ning sotsiaalset intelligentsust (Griffin, McGaw, \& Care, 2012). Tekkinud on vajadus loodusteadusliku kirjaoskusega tööjõu järele, kellel on hea analüüsi- ja järeldusvõime ning oskus teha meeskonnatööd ja rakendada teadmisi uutes olukordades (Brown, Reveles, \& Kelly, 2005; Bybee \& Fuchs, 2006; European Commission, 2010; Fensham, 2004; Holbrook, 2014; Ravenscroft, Lindstaedt, Kloos, \& Hernández-Leo, 2012).

Siinses uurimuses käsitletakse bioloogia-alast kirjaoskust loodusteadusliku kirjaoskuse osana, mille ainealane fookus on bioloogiateadmistel ning mis on oma olemuselt interdistsiplinaarne (bioloogiast kui teadusharust on arenenud välja näiteks rakendusbioloogia, raku- ja embrüotehnoloogia, genoomika, geenitehnoloogia, insenergeneetika, biotehnoloogia). Kitsenduse põhjus on ka asjaolu, et nagu teised ainevaldkondade teadmised, on ka bioloogiateadmised ainespetsiifilised (Furnham, Batey, Booth, Patel, \& Lozinskaya, 2011), mis omakorda tingib ka nende teadmiste rakendamise oskuste spetsiifilisuse, eriti probleemide looval lahendamisel ning otsuste 
vastuvõtmisel ja põhjendamisel, mille puhul on väga suur osakaal juba omandatud aineteadmistel (Kim, Roh, \& Cho, 2016). Seega tunneb bioloogia-alase kirjaoskusega inimene ära probleemid (sh igapäevaelulised), mille sisu on seotud bioloogiaga, ning rakendab nende lahendamiseks bioloogiatundides omandatud teadmisi ja oskusi, seejuures mõistab bioloogiateemalisi artikleid, oskab arutleda probleemide sisu üle ja otsida vajalikku infot ning teeb põhjendatud otsuseid nii isiklikus plaanis kui ka ühiskonna tasandil (Demastes \& Wandersee, 1992; Uno \& Bybee, 1994).

Eesti huvigruppide (tööandjate, ettevõtjate, teadlaste, õpetajate jt) uuringust selgus, et nende arvamuse kohaselt peetakse aineteadmistest olulisemaks oskust rakendada teadmisi uutes olukordades, samuti analüüsi- ja interpreteerimisoskust ning olulise eristamist ebaolulisest. Niisamuti on tähtis otsuste vastuvõtmine ja põhjendamine mitmest aspektist. Loovale mõtlemisele lisaks tähtsustati uuenduslikkust, info loova kasutamise oskust ja uute ideede kasutamist igapäevaelulistes olukordades. Kõik huvigrupid pidasid oluliseks, et peale aineteadmiste tuleb kindlasti arendada ka oskusi ja pädevusi, samuti väljendus nende hinnangutes gümnaasiumilõpetajate kui tulevaste tööjõuturu liikmete koostöö- ja suhtlusoskuste ning loova mõtlemise oskuste suur tähtsus (Laius et al., 2015a; Laius et al., 2016).

Järgnevalt on kirjandusallikatele tuginedes kirjeldatud praegusse uurimusse valitud bioloogia-alase kirjaoskuse komponente ning nende arendamist ja hindamist koolis.

\section{Aineteadmised bioloogia-alase kirjaoskuse komponendina}

Gümnaasiumi riikliku õppekava bioloogia ainekavas (2011) rõhutatakse õpilase jaoks tähtsate komponentidena bioloogiateadmisi (nt inimese organismi talitlus, ainevahetusprotsessid kehas, toitainete seedimine ja imendumine, inimese ainevahetuslikud evolutsioonilised muutused ja muutlikkus, kasulikud ja kahjulikud mutatsioonid inimesel), oskusi ning hoiakuid. Õpilase aineteadmised on vajalikud probleemide lahendamisel ja/või otsuste vastuvõtmisel ja põhjendamisel ning õpilased, kellel on head aineteadmised, suudavad nende kaasabil probleeme lahendada oluliselt efektiivsemalt kui need õpilased, kelle aineteadmised on nõrgad (Sadler \& Zeidler, 2005).

\section{Probleemide lahendamise oskus bioloogia-alase kirjaoskuse komponendina}

Gümnaasiumi riikliku õppekava järgi rakendab õpilane loodusteaduslikku meetodit bioloogiaprobleeme lahendades: planeerib, viib läbi ning analüüsib vaatlusi ja katseid ning esitab saadud tulemusi korrektselt verbaalses 
ja visuaalses vormis. Samuti oskab õpilane langetada loodus- ja sotsiaalkeskkonnaga seotud kompetentseid otsuseid ning prognoosida otsuste tagajärgi, analüüsida ja hinnata kriitiliselt neis sisalduvat teavet ning rakendada seda tulemuslikult protsesse selgitades ja probleeme lahendades (Gümnaasiumi riiklik õppekava, 2011). Probleemide lahendamise oskuse arendamine bioloogias on oluline seepärast, et selle kaudu arenevad nii aineteadmiste rakendamise oskus, iseseisva ja meeskonnatöö oskus, kriitilise mõtlemise oskus kui ka sotsiaalsed oskused. Probleemide lahendamise oskus aitab õpilastel tulevikus vähendada väärarusaamade teket, tõhustada aineteadmiste rakendamise oskust ning suhtlus- ja eneseväljendusoskust. Probleemide lahendamise oskuse arendamine bioloogias võimaldab õpilastel igapäevaseid või tööalaseid probleeme paremini ette näha ning neid efektiivselt lahendada (Cliff \& Curtin, 2000; Gürses, Açıkyıldız, Doğar, \& Sözbilir, 2007; Şenocak, Taşkesenligil, \& Sözbilir, 2007). Uuringud on näidanud, et efektiivseks osutub vaid niisugune õpetamine, mille õpitulemusi õpetajad koolitundides reaalselt hindavad, seega on väga oluline töötada välja ja katsetada niisuguseid teste, mille abil hinnatakse peale aineteadmiste ka oskusi (Lile \& Bran, 2014).

\section{Otsuse tegemine ja põhjendamine bioloogia-alase kirjaoskuse komponendina}

Gümnaasiumi riiklikus õppekavas sätestatakse, et õpilane peab suutma langetada igapäevaeluga seotud pädevaid otsuseid, tuginedes teaduslikele, majanduslikele ja eetilis-moraalsetele seisukohtadele, arvestades ning prognoosides otsuste tagajärgi (Gümnaasiumi riiklik óppekava, 2011). Sotsiaal-teadusliku sisuga probleemide lahendamine bioloogiatunnis arendab õpilastes oskust iseseisvalt vastu võtta põhjendatud ja argumenteeritud otsuseid, mis lähtuvad bioloogiateadmistest. Otsuste tegemise ja vastuvõtmise arendamine bioloogiatunnis ei asenda küll täielikult reaalelulist olukorda, kuid annab võimaluse õpilastel kokku puutuda igapäevaeluliste olukordadega, millel on mitu lahendit, ning end nendeks ette valmistada (Steffen \& Hößle, 2016). Varasemad uuringud (Kahan et al., 2012; Papadouris \& Constantinou, 2010) on näidanud, et igapäevaelulise otsuse tegemisel ei osutu alati määravaks loodusteaduslikud teadmised, aga kuna koolibioloogia kontekstis ei ole seda teemat varem uuritud, siis on praeguses uurimistöös võetud üheks uuritavaks komponendiks just sotsiaalteadusliku otsuse tegemine. 


\section{Loodusteaduslik loov mõtlemine bioloogia-alase kirjaoskuse komponendina}

Gümnaasiumi riikliku õppekava bioloogia ainekavas (Gümnaasiumi riiklik õppekava, 2011) rõhutatakse, et bioloogiaõpe arendab loodusteaduste- ja tehnoloogiaalast kirjaoskust, loovust ning süsteemset mõtlemist. Loov mõtlemine ja loovus annavad õpilasele võimaluse jõuda uute ideede, lähenemisviiside või lahendusteni, mis võivad erineda tavapärastest olukordadest (Csikszentmihalyi, 1996; Sternberg, Kaufman, \& Pretz, 2002). Loovuse uurijad on jõudnud järeldusele, et loovust tuleks arendada igapäevaeluliste probleemide lahendamise kaudu (Basadur, Gelade, \& Basadur, 2014). Loovuse abil on võimalik õpilastel lahendada nii isiklikke kui ka sotsiaalse suunitlusega probleeme või ülesandeid, millel on teaduslik sisu, ning uue loova lahenduseni jõudmiseks tuleb olemasolevad teadmised kaasata probleemilahenduse protsessi, olles seejuures avatud mitmetele võimalustele ning ebatraditsioonilistele lähenemisviisidele (Heller, 2007; Mumford, Hester, \& Robledo, 2010).

Loodusteadusliku loovusena defineerivad Usta ja Akkanat (2015) uudsete, ebatavaliste ja kasulike teadmiste, teooriate, lahenduskäikude või toodete loomist varasemate loodusteadustest omandatud teadmiste ja oskuste põhjal. Piiratud mahuga kirjaliku bioloogia-alase kirjaoskuse testi kaudu mõõdetakse praeguses uurimuses gümnaasiumiõpilaste loodusteaduslikku loovust voolavusena (ingl fluency), mida on viimasel ajal mitmetes uuringutes kasutatud loovust iseloomustava parameetrina (Batey, ChamorroPremuzic, \& Furnham, 2009; Furnham et al., 2011; Tsakanikos \& Claridge, 2005). Sisuliselt on voolavus õpilaste pakutud erinevate vastuste koguarv, mis iseloomustab divergentset mõtlemist (Demir \& Şahin, 2014).

Kuigi gümnaasiumi riiklik õppekava (2011) eesmärgistab gümnaasiumilõpetajate kompetentsusi, mis vastavad üldjoontes ühiskonna huvigruppide ootustele, ning gümnaasiumis kasutatavates õpikutes on esitatud bioloogiateadmiste rakendamist eeldavaid ülesandeid, puudub tõenduspõhine info Eesti gümnaasiumiõpilaste bioloogia-alase kirjaoskuse kognitiivsete komponentide tegeliku olukorra kohta.

Lisaks ei ole loodusteaduslike ainete õpitulemustes siiani kadunud erinevused tüdrukute ja poiste vahel, kuid rahvusvahelise PISA 2015 uuringu andmetel ei saa neid enam lihtsustatult interpreteerida tüdrukute raskusena heade tulemuste saavutamisel ja poiste pingutusena baastaseme saavutamisel. Kui varem on erinevuste põhjuseks peetud erinevaid hoiakuid loodusteaduste õppimise suhtes, siis viimased uuringud viitavad pigem riigist tulenevatele sotsiaalsetele teguritele, mida saavad mõjutada nii vanemad, õpetajad kui ka ühiskonna huvigrupid ja arvamusliidrid (OECD, 2016). 


\section{Metoodika}

\section{Instrument}

Instrumendi koostamiseks analüüsiti Eestis tehtud uuringut (Laius et al., 2015a; Laius et al., 2016), mille eesmärk oli välja selgitada, millised on huvigruppide ootused gümnaasiumiõpilaste teadmiste ja oskuste suhtes, mida arendatakse loodusainete, sh bioloogiatundides. Delphi meetodil läbi viidud huvigruppide arvamuste analüüsi (Laius et al., 2016) kasutades valiti bioloogia-alase kirjaoskuse testi koostamise aluseks peale bioloogia-alaste teadmiste ka kolm huvigruppide enim mainitud gümnaasiumilópetajatele vajalikku oskust: probleemide lahendamise oskus, loodusteadusliku loova mõtlemise oskus ning otsuste tegemise ja põhjendamise oskus, mis kattuvad siinses töös bioloogia-alase kirjaoskuse kognitiivsete komponentidega, mida loodud test mõõdab (II-IV komponent, joonis 1, tabel 1). Kuigi bioloogiateadmiste komponenti ei pidanud huvigrupid kõige olulisemaks arendamist vajavaks bioloogia-alase kirjaoskuse kognitiivseks komponendiks, hinnati seda teiste komponentide realiseerimise seisukohalt vajalikuks ning lisati seetõttu I komponendina instrumenti (joonis 1, tabel 1).

Laktoositalumatuse kui testi aluseks oleva teema valiku tingis asjaolu, et selle teema aktuaalsus Eesti ühiskonnas on viimastel aastatel oluliselt kasvanud, samuti on suurenenud inimeste teadlikkus laktoositalumatusega kaasnevatest kehalistest vaevustest (Lember et al., 2007). Ka on globaliseeruv maailm toonud kaasa üha tiheneva kokkupuute inimestega nendest piirkondadest, kus teadlikkus laktoositalumatusest on juba pikka aega olnud suurem ning laktoositalumatust on diagnoositud rohkematel inimestel (Ida-Tallinna Keskhaigla, 2009). Eestis on teaduslike uuringutega kindlaks tehtud, et $25 \%$ populatsioonist on suuremal või vähemal määral laktoositalumatu. Ka kaupluste tootevalikus on viimastel aastatel oluliselt suurenenud laktoosivabade toode arv (Tervise Arengu Instituut, 2016).

Gümnaasiumi riikliku õppekava (2011) bioloogia ainekavas kirjeldatakse inimese talitluse regulatsiooni, muu hulgas mainitakse seedeelundkonna ehituse ja talitluse tundmist, mis annab ainealase eelduse mõista laktoositalumatuse bioloogilist olemust. Lisaks sai laktoositalumatuse teema valikul määravaks asjaolu, et sellega haakub hulgaliselt aineteadmisi, mida on kajastatud bioloogiaõpikutes (lisad 1 ja 2) ning mis on testi ülesannete eduka lahendamise eeldus.

Uuringu tarbeks koostati bioloogia-alase kirjaoskuse test, milles käsitleti laktoositalumatuse teemat ning milles pöörati tähelepanu neljale komponendile ja nende hindamisele, mida illustreerib joonis 1 . Koostatud testi ülesannete sisu kirjeldused komponentide kaupa ning nende lahendamiseks vajalikud teadmised ja oskused on toodud tabelis 1 . 
Tabel 1. Bioloogia-alase kirjaoskuse testi ülesannete kirjeldus ning vastamiseks vajalikud teadmised ja oskused

\begin{tabular}{|c|c|c|}
\hline $\begin{array}{l}\text { Ülesande } \\
\text { number }\end{array}$ & Ülesande sisu kirjeldus & $\begin{array}{l}\text { Ülesande lahendamiseks vajalikud } \\
\text { teadmised ja oskused }\end{array}$ \\
\hline 1 & Laktoositalumatuse mõiste & Aineteadmiste reprodutseerimine \\
\hline 2 & $\begin{array}{l}\text { Piimatoodete laktoosisisaldus } \\
\text { ja laktoosi vähendamine } \\
\text { piimatoodetes (seedimine ja } \\
\text { käärimine) }\end{array}$ & $\begin{array}{l}\text { Aineteadmiste kasutamine probleemide } \\
\text { lahendamisel ja põhjendamisel - laktoosi } \\
\text { vähendamine laktoositalumatute } \\
\text { piimatoodete hapendamisel }\end{array}$ \\
\hline 3 & $\begin{array}{l}\text { Tabeli andmete abil järelduste } \\
\text { tegemine ja põhjenduste } \\
\text { esitamine }\end{array}$ & $\begin{array}{l}\text { Aineteadmiste kasutamine probleemide } \\
\text { lahendamisel ja põhjendamisel - piim- } \\
\text { happebakterite ja seente rolli põhjenda- } \\
\text { mine piimasaaduste kääritamisel (tabeli } \\
\text { andmete analüüsimine) }\end{array}$ \\
\hline 4 & $\begin{array}{l}\text { Evolutsioonilised eelised, } \\
\text { mille laktoosi talumine annab } \\
\text { põhjamaade rahvastele }\end{array}$ & $\begin{array}{l}\text { Loova/divergentse mõtlemise oskus } \\
\text { laktoositaluvuse eeliste evolutsioonilise } \\
\text { väljakujunemise kontekstis }\end{array}$ \\
\hline 5 & $\begin{array}{l}\text { Konteksti abil seedimis- ja } \\
\text { lagundamisprotsesside olemuse } \\
\text { mõistmine ning selle kaudu } \\
\text { probleemi lahendamine ja } \\
\text { selgitamine }\end{array}$ & $\begin{array}{l}\text { Teadusliku probleemi lahendamine } \\
\text { keerulises integreeritud kontekstis, kus on } \\
\text { vaja mõista nii seedimise olemust kui ka } \\
\text { disahhariidide ensümaatilist lagundamist }\end{array}$ \\
\hline 6 & $\begin{array}{l}\text { Võimalused vältida luumurdude } \\
\text { ja osteoporoosi tekkepõhjuse } \\
\text { riski }\end{array}$ & $\begin{array}{l}\text { Aineteadmiste kasutamine probleemide } \\
\text { lahendamisel ja põhjendamisel - laktoosi- } \\
\text { talumatutel Ca-puuduse kui võimaliku } \\
\text { luumurdude ja osteoporoosi tekkepõhjuse } \\
\text { riski vältimise võimaluste põhjendamine } \\
\text { muude toodete kui piimatoodete tarbimisel }\end{array}$ \\
\hline 7 & $\begin{array}{l}\text { Laktoositalumatuse pärilikkus } \\
\text { kolmikutel }\end{array}$ & Aineteadmiste reprodutseerimine \\
\hline 8 & $\begin{array}{l}\text { Menüü koostamine } \\
\text { laktoositalumatutele ja } \\
\text { valikute põhjendamine } \\
\text { mitmest aspektist }\end{array}$ & $\begin{array}{l}\text { Sotsiaalse suunitlusega teadusliku } \\
\text { probleemi lahendamiseks otsuse tegemine } \\
\text { ja põhjendamine mitmest aspektist }\end{array}$ \\
\hline
\end{tabular}

Iga ülesande puhul hinnati selle saavutustaset ehk õpilaste keskmise tulemuse protsentuaalset osakaalu võimalikust maksimaalsest tulemusest. Ülesannete saavutustasemete alusel eristusid kolm saavutustaseme gruppi (kõrge, keskmine ja madal), mille keskmiste tulemuste hindamine on kooskõlas gümnaasiumi riiklikus õppekavas (2011) esitatud hindamiskriteeriumitega (joonis 1) ja mis $\chi^{2}$-testi põhjal eristuvad üksteisest oluliselt $(p=0,000)$. 

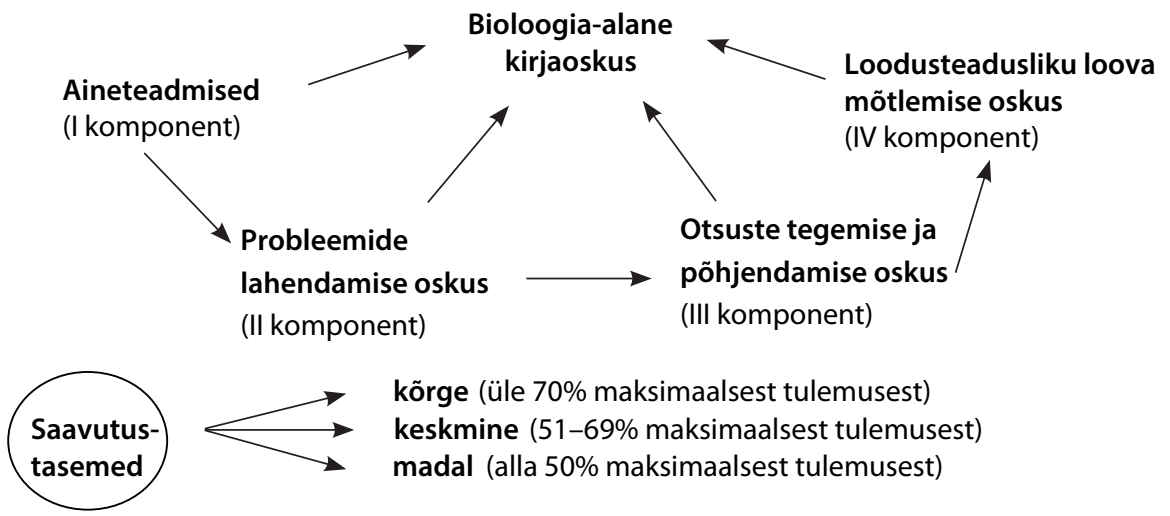

Joonis 1. Bioloogia-alase kirjaoskuse kognitiivsed komponendid ja nende saavutustaseme hindamine praeguse töö kontekstis

Õpilaste vastused kodeeriti järgmisel viisil:

- ülesandele vastamata jätmine või täiesti vale vastus - 0;

- nõrk vastus (ülesandes esitatud info kordamine vastusena või väga vähese info esitamine, mis ei ole ülesandega piisavalt seotud) - 1;

- osaliselt õige vastus (osaliselt või täielikult õige vastus, mida ei ole õigesti põhjendatud) - 2;

- õige vastus (korrektne vastus koos õige põhjendusega, vajaduse korral põhjendatud ka mitmest aspektist) - 3 .

Koostatud instrumenti katsetati 36 õpilasega 11. klassist ühes Tartu linna gümnaasiumis ja testi tagasiside põhjal tehti mõningaid muudatusi küsimuste sõnastuses. Instrumendi valiidsus on tagatud eksperdimeetodiga: ülesannete sobivust hindasid kolm sõltumatut eksperti (üks kogenud bioloogiaõpetaja ning kaks loodusteadusliku hariduse teadurit), kes aitasid tagada ka ülesannete hindamise sisulist valiidsust.

Õpilaste vastuseid kodeerisid kaks uurijat ning nende hinnangud olid $82 \%$ ulatuses kooskõlas. Instrumendi reliaabluse näitaja Cronbachi $\alpha$ on piisav $(0,63)$, arvestades, et ülesannete arv instrumendis oli väike (Loewenthal, 2004). $\chi^{2}$-testiga määrati õpilaste kolme saavutustaseme (kõrge, keskmine, madal) erinevuste olulisus ning kõikidel juhtudel $p=0,000$.

\section{Valim}

Valim moodustati juhuvalimi meetodil (Johnson \& Christensen, 2000): eesti õppekeelega koolide nimekirjast kaasati uuringusse iga neljas kool. Valimi moodustasid 1116 õpilast 10. klassist (598 tüdrukut ja 518 poissi) 
ja 932 õpilast 11. klassist (498 tüdrukut ja 434 poissi) 44st Eesti gümnaasiumist (kokku 2048 õpilast, sh 1096 naissoost ja 952 meessoost õpilast). Valimisse kuuluvatest koolidest osalesid uuringus kõik väljavalitud gümnaasiumiklasside õpilased, kes olid testi tegemise päeval koolis.

\section{Andmete analïïs}

Andmeid analüüsiti programmiga IBM SPSS 22. Rühmadevahelise statistiliselt olulise erinevuse kindlakstegemiseks kasutati sõltumatute valimite jaoks mitteparameetrilisi Manni-Whitney ja Kruskalli-Wallise teste, sest andmeid analüüsiti kvalitatiivse kodeerimise teel. Et hinnata valimi suuruse mõju saadud tulemuste erinevustele, arvutati mõju suuruse Coheni $d$ (Cohen, 1988) ning saavutustasemete erinevuste olulisus määrati $\chi^{2}$-testi abil.

\section{Tulemused}

Bioloogia-alase kirjaoskuse testi tulemuste analüüsimine ülesannete kaupa (tabel 2) näitab, et õpilaste keskmised tulemused ning ka ülesannetele vastamata jätmise osakaal varieeruvad suures vahemikus (vastavalt 1,32-2,58 ja $0,2-20,8 \%)$. Ülesannete vastuste keskmised tulemused esitati protsendina võimalikust maksimaalsest tulemusest (3) ning nende alusel loodi kolm hierarhilist saavutustaset (kõrge, keskmine ja madal), mille hindamine kooskõlastati gümnaasiumi riiklikus õppekavas määratud hindamisskaalaga (joonis 1).

10. ja 11. klassi ópilased vastasid testi ülesannetele sarnaselt. Ainult kolme ülesande puhul kaheksast (ülesanded 1, 4 ja 6) esineb 10. ja 11. klassi õpilaste keskmistes tulemustes statistiliselt usaldusväärseid erinevusi, mis aga suure valimi tõttu ei oma erilist kaalu. Nimelt ei ole ühegi ülesande puhul mõju suurus piisav (Coheni $d<0,2$ ) selleks, et nendel erinevustel oleks sisuline pedagoogiline väärtus, mis väljendaks tulemuste olulist paranemist.

Ülesannete lahendamise keskmiste tulemuste analüüsimisel selgus, et õpilaste vastuste alusel jagunevad ülesanded kolme hierarhilise saavutustaseme - madala, keskmise ja kõrge - vahel (tabel 3, joonis 2). Kõrge saavutustaseme ülesanded eeldasid õpilastelt aineteadmiste reprodutseerimist (I komponent, tabel 1), keskmise saavutustaseme ülesanded teadmiste kasutamist probleemide lahendamisel (II komponent, tabel 1), madala saavutustaseme ülesanded loodusteadusliku loova mõtlemise voolavust (IV komponent, tabel 1) ning otsuse vastuvõtmist ja põhjendamist mitmest aspektist (III komponent, tabel 1). Õpilastele osutus väga keerukaks aine- 
sisuga probleemilahendusülesanne, mille lahendamiseks oli vaja mõista seedimise ja laktoositalumatuse olemust ning rakendada seda teadmist uues situatsioonis (selle ülesande saavutustase oli madal). Uurimistulemustest ilmneb, et mida enam erineb ülesande iseloom harjumuspärasest, seda madalam on saavutustase, eriti III ja IV komponendi puhul, mille saavutustase on madal (alla 50\%).

10. ja 11. klassi õpilaste tulemuste võrdleval analüüsimisel selgus (tabel 3), et kõikide ülesannete saavutustasemete poolest on 11. klassi õpilased veidi paremate tulemustega (madala saavutustasemega ülesannete puhul statistiliselt usaldusväärselt), kuid kuna valimi mõju suurus on kõikidel saavutustasemetel väike (Coheni $d<0,2$ ), siis ei saa neid tulemusi sisuliselt tähendusrikkalt erinevaks pidada, sest keskmine erinevus 0,06 ei näita märkimisväärset tulemuste paremust.

Tabel 2. 10. ja 11. klassi õpilaste bioloogiatesti tulemused kõikide ülesannete puhul

\begin{tabular}{|c|c|c|c|c|c|c|c|}
\hline Klass & $\begin{array}{c}\text { Üles- } \\
\text { ande } \\
\text { number }\end{array}$ & $\begin{array}{c}\text { Vastamata } \\
\text { ülesandeid } \\
(\%)\end{array}$ & $\begin{array}{l}\text { Keskmine } \\
\text { tulemus } \\
(S D)\end{array}$ & $\begin{array}{l}\text { Saavu- } \\
\text { tustase } \\
(\%)\end{array}$ & $\begin{array}{l}\text { Wilcoxoni } \\
\text { test } \\
(Z)\end{array}$ & $p$ & $\begin{array}{c}\text { Mõju } \\
\text { suurus } \\
\text { (Coheni } d \text { ) }\end{array}$ \\
\hline 10. kl & \multirow[t]{2}{*}{1} & 0,4 & $2,32(0,52)$ & 77,3 & \multirow[t]{2}{*}{$-3,079$} & \multirow[t]{2}{*}{0,002} & \multirow[t]{2}{*}{0,111} \\
\hline 11. kl & & 0,2 & $2,38(0,56)$ & 79,3 & & & \\
\hline 10. kl & \multirow[t]{2}{*}{2} & 0,5 & $1,68(0,87)$ & 56,0 & \multirow[t]{2}{*}{$-1,089$} & \multirow[t]{2}{*}{0,276} & \multirow[t]{2}{*}{0,057} \\
\hline 11. kl & & 0,5 & $1,73(0,89)$ & 57,7 & & & \\
\hline 10. kl & \multirow[t]{2}{*}{3} & 17,1 & $2,06(0,54)$ & 68,7 & \multirow[t]{2}{*}{$-0,791$} & \multirow[t]{2}{*}{0,429} & \multirow[t]{2}{*}{0,071} \\
\hline 11. kl & & 17,5 & $2,10(0,58)$ & 70,0 & & & \\
\hline 10. $\mathrm{kl}$ & \multirow[t]{2}{*}{4} & 20,8 & $1,44(0,63)$ & 48,0 & \multirow[t]{2}{*}{$-3,194$} & \multirow[t]{2}{*}{0,001} & \multirow[t]{2}{*}{0,157} \\
\hline 11. kl & & 18,9 & $1,54(0,64)$ & 51,6 & & & \\
\hline 10. $\mathrm{kl}$ & \multirow[t]{2}{*}{5} & 11,6 & $1,33(0,66)$ & 44,3 & \multirow[t]{2}{*}{$-0,199$} & \multirow[t]{2}{*}{0,842} & \multirow[t]{2}{*}{0,015} \\
\hline 11. kl & & 12,1 & $1,32(0,65)$ & 44,0 & & & \\
\hline 10. kl & \multirow[t]{2}{*}{6} & 2,9 & $2,14(0,43)$ & 71,3 & \multirow[t]{2}{*}{$-2,187$} & \multirow[t]{2}{*}{0,029} & \multirow[t]{2}{*}{0,112} \\
\hline 11. kl & & 2,9 & $2,19(0,46)$ & 73,0 & & & \\
\hline 10. $\mathrm{kl}$ & \multirow[t]{2}{*}{7} & 5,4 & $2,58(0,79)$ & 86,0 & \multirow[t]{2}{*}{$-0,104$} & \multirow[t]{2}{*}{0,918} & \multirow[t]{2}{*}{0,013} \\
\hline 11. kl & & 4,5 & $2,57(0,79)$ & 85,7 & & & \\
\hline 10. kl & \multirow[t]{2}{*}{8} & 5,2 & $1,54(0,61)$ & 51,3 & \multirow[t]{2}{*}{$-0,031$} & \multirow[t]{2}{*}{0,976} & \multirow[t]{2}{*}{0,033} \\
\hline 11. kl & & 6,1 & $1,56(0,61)$ & 52,0 & & & \\
\hline
\end{tabular}


Tabel 3. 10. ja 11. klassi õpilaste bioloogiatesti tulemused ülesannete saavutustasemete kaupa

\begin{tabular}{|c|c|c|c|c|c|c|c|}
\hline $\begin{array}{l}\text { Saavutus- } \\
\text { tase }\end{array}$ & $\begin{array}{c}\text { Ülesande } \\
\text { number }\end{array}$ & $\begin{array}{c}\text { Klass } \\
(10 . \mathrm{kl} \\
N=1116 ; \\
11 . \mathrm{kl} \\
N=932)\end{array}$ & $\begin{array}{l}\text { Keskmine } \\
\text { tulemus } \\
(S D)\end{array}$ & $\begin{array}{l}\text { Saavu- } \\
\text { tustase } \\
(\%)\end{array}$ & $\begin{array}{c}\text { Manni- } \\
\text { Whitney } \\
\text { test } \\
\text { (Z) }\end{array}$ & $p$ & $\begin{array}{c}\text { Mõju } \\
\text { suurus } \\
\text { (Coheni } d \text { ) }\end{array}$ \\
\hline \multirow{3}{*}{$\begin{array}{c}\text { I- } \\
\text { kõrge }\end{array}$} & \multirow{2}{*}{1,7} & 10. kl & $2,44(0,49)$ & 81,3 & \multirow{2}{*}{$-1,683$} & \multirow{2}{*}{0,092} & \multirow{2}{*}{0,061} \\
\hline & & 11. kl & $2,47(0,50)$ & 82,3 & & & \\
\hline & & erinevus & $+0,03$ & & & & \\
\hline \multirow{3}{*}{$\begin{array}{c}\text { II - } \\
\text { keskmine }\end{array}$} & \multirow{2}{*}{$2,3,6$} & 10. kl & $1,94(0,43)$ & 64,7 & \multirow{2}{*}{$-2,232$} & \multirow{2}{*}{0,026} & \multirow{2}{*}{0,114} \\
\hline & & $11 . \mathrm{kl}$ & $1,99(0,45)$ & 66,3 & & & \\
\hline & & erinevus & $+0,05$ & & & & \\
\hline \multirow{3}{*}{$\begin{array}{c}\text { III - } \\
\text { madal }\end{array}$} & \multirow{2}{*}{$4,5,8$} & 10. kl & $1,43(0,44)$ & 47,7 & \multirow{2}{*}{$-2,196$} & \multirow{2}{*}{0,028} & \multirow{2}{*}{0,045} \\
\hline & & 11. kl & $1,45(0,42)$ & 48,3 & & & \\
\hline & & erinevus & $-0,02$ & & & & \\
\hline
\end{tabular}

Kõrge keskmine saavutustase (üle 70\%) aineteadmisi nõudvatele küsimustele vastamisel näitab, et aineteadmiste reprodutseerimisega ei ole õpilastel laktoositalumatuse kontekstis probleeme. Esitatud andmete analüüsimiseks vajalike teadmiste rakendamise, nt probleemide lahendamise oskuste tase oli keskmine (50-69\%). Otsuse tegemise ja põhjendamise ning loodusteadusliku loovuse voolavust nõudvate ülesannete tulemused olid madalal saavutustasemel (alla 50\%). Madala saavutustasemega ülesannetest osutus õpilastele kõige raskemaks (44\%) ülesanne 5 (laktoositalumatuse diagnoosimine), mis oli probleemi lahendamise ülesanne keerukas ja integreeritud ainekontekstis, mis eeldas seedimisprotsessi ja ensümaatilise lagunemise mõistmist. Tulemused näitavad, et ülesannete saavutustasemed on kooskõlas ülesannete jaotusega komponentideks, st I komponent (ainealane) on kõrgel, II komponent (probleemi lahendamine) on keskmisel ning III komponent (otsuse tegemine ja põhjendamine) ja IV komponent (loovus) on madalal saavutustasemel, kuhu erandina kuulub ka ülesanne 5 (mitmetahulise probleemi lahendamine, ingl complex problem solving).

Jooniselt 2 on näha, et kõrge saavutustasemega küsimuste vastuste analüüsimisel saadud keskmised tulemused on ligikaudu kaks korda paremad kui väga madala saavutustasemega küsimuste tulemused, näidates suurt saavutustasemete erinevust õpilaste aineteadmiste reprodutseerimises ning teadmiste ülekandmises uude ja keerukasse situatsiooni. 


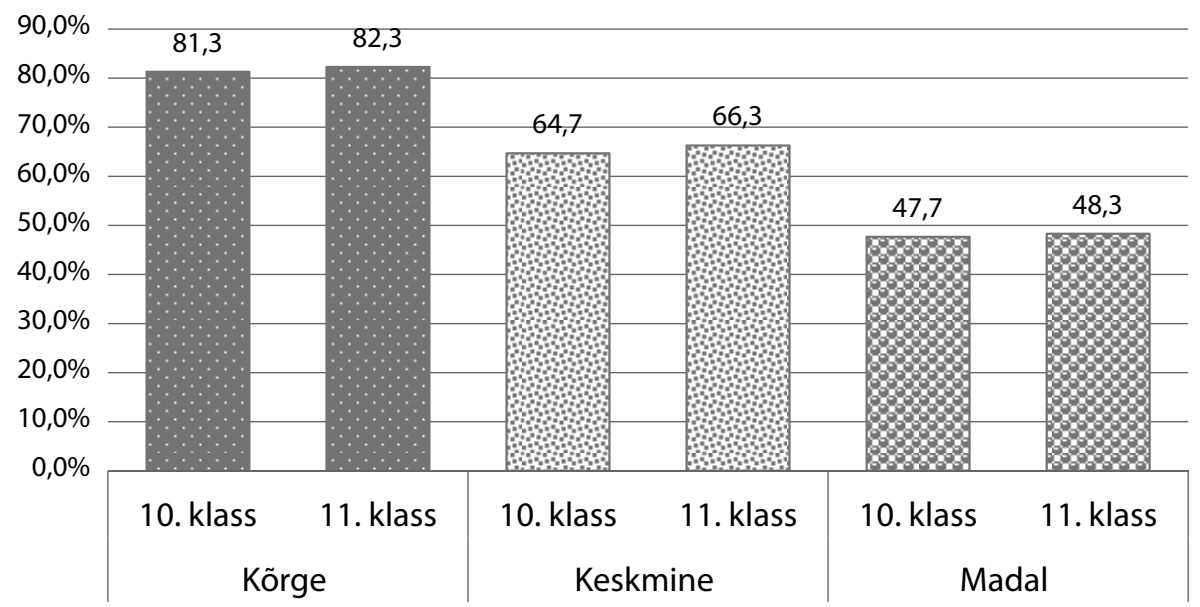

\section{Saavutustasemed}

Joonis 2. 10. ja 11. klassi õpilaste tulemuste jaotus saavutustasemete alusel

Sugudevahelisi erinevusi analüüsiti klasside kaupa. 10. klassi õpilaste tulemused näitavad, et poiste ja tüdrukute võrdluses on tüdrukutel kõrge ja keskmise saavutustasemega ülesannete vastuste puhul statistiliselt oluline paremus (tabel 4). Samas näitab valimi suurusest tingitud väike mõju (Coheni $d<0,2$ ), et 10. klassi tüdrukute ja poiste tulemustes ei ole bioloogia-alase kirjaoskuse komponentide tulemuste erinevusel sisulist väärtust.

Tabel 4. 10. klassi õpilaste sugudevahelised erinevused bioloogia-alase kirjaoskuse keskmistes tulemustes saavutustasemete kaupa

\begin{tabular}{|c|c|c|c|c|c|c|}
\hline $\begin{array}{l}\text { Saavutus- } \\
\text { tase }\end{array}$ & $\begin{array}{c}\text { Sugu } \\
(N=598, \\
M=518)\end{array}$ & $\begin{array}{l}\text { Keskmine } \\
\text { tulemus } \\
(S D)\end{array}$ & $\begin{array}{l}\text { Saavutus- } \\
\text { tase } \\
(\%)\end{array}$ & $\begin{array}{c}\text { Manni- } \\
\text { Whitney test } \\
(Z)\end{array}$ & $p$ & $\begin{array}{c}\text { Mõju } \\
\text { suurus } \\
\text { (Coheni } d \text { ) }\end{array}$ \\
\hline \multirow{3}{*}{$\begin{array}{c}\text { I- } \\
\text { kõrge }\end{array}$} & $N$ & $2,49(0,46)$ & 83,0 & \multirow{2}{*}{$-2,883$} & \multirow{2}{*}{0,004} & \multirow{2}{*}{0,187} \\
\hline & M & $2,40(0,50)$ & 80,0 & & & \\
\hline & erinevus & $-0,09$ & & & & \\
\hline \multirow{3}{*}{$\begin{array}{c}\text { II - } \\
\text { keskmine }\end{array}$} & 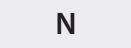 & $1,96(0,43)$ & 65,3 & \multirow{2}{*}{$-1,995$} & \multirow{2}{*}{0,046} & \multirow{2}{*}{0,092} \\
\hline & M & $1,92(0,44)$ & 64,0 & & & \\
\hline & erinevus & $-0,04$ & & & & \\
\hline \multirow{3}{*}{$\begin{array}{l}\text { III - } \\
\text { madal }\end{array}$} & $N$ & $1,46(0,45)$ & 48,7 & \multirow{2}{*}{$-1,667$} & \multirow{2}{*}{0,095} & \multirow{2}{*}{0,138} \\
\hline & M & $1,40(0,42)$ & 46,7 & & & \\
\hline & erinevus & $-0,06$ & & & & \\
\hline
\end{tabular}


11. klassi tüdrukute tulemused on nii kõrge kui ka madala saavutustasemega ülesannete puhul statistiliselt oluliselt paremad kui poistel (tabel 5). Samas näitab valimi suurusest tingitud väike mõju (Coheni $d<0,2$ ), et ka 11. klassi tüdrukute ja poiste tulemustes ei ole bioloogia-alase kirjaoskuse komponentide tulemuste erinevusel sisulist väärtust.

Tabel 5. 11. klassi õpilaste sugudevahelised erinevused bioloogia-alase kirjaoskuse keskmistes tulemustes saavutustasemete kaupa

\begin{tabular}{|c|c|c|c|c|c|c|}
\hline $\begin{array}{l}\text { Saavutus- } \\
\text { tase }\end{array}$ & $\begin{array}{c}\text { Sugu } \\
(N=498, \\
M=434)\end{array}$ & $\begin{array}{l}\text { Keskmine } \\
\text { tulemus } \\
(S D)\end{array}$ & $\begin{array}{l}\text { Saavutus- } \\
\text { tase } \\
(\%)\end{array}$ & $\begin{array}{c}\text { Manni- } \\
\text { Whitney test } \\
(Z)\end{array}$ & $p$ & $\begin{array}{c}\text { Mõju } \\
\text { suurus } \\
\text { (Coheni } d \text { ) }\end{array}$ \\
\hline \multirow{3}{*}{$\begin{array}{c}\text { I- } \\
\text { kõrge }\end{array}$} & $\mathrm{N}$ & $2,51(0,48)$ & 83,7 & \multirow{2}{*}{$-2,627$} & \multirow{2}{*}{0,009} & \multirow{2}{*}{0,199} \\
\hline & $M$ & $2,41(0,52)$ & 80,3 & & & \\
\hline & erinevus & $-0,10$ & & & & \\
\hline \multirow{3}{*}{$\begin{array}{c}\text { II - } \\
\text { keskmine }\end{array}$} & $\mathrm{N}$ & $1,99(0,44)$ & 66,3 & \multirow{2}{*}{$-1,671$} & \multirow{2}{*}{0,095} & \multirow{2}{*}{0,111} \\
\hline & M & $1,94(0,46)$ & 64,7 & & & \\
\hline & erinevus & $-0,05$ & & & & \\
\hline \multirow{3}{*}{$\begin{array}{c}\text { III - } \\
\text { madal }\end{array}$} & $N$ & $1,48(0,39)$ & 49,3 & \multirow{2}{*}{$-3,669$} & \multirow{2}{*}{0,000} & \multirow{2}{*}{0,197} \\
\hline & M & $1,40(0,42)$ & 46,7 & & & \\
\hline & erinevus & $-0,08$ & & & & \\
\hline
\end{tabular}

Seega ilmnes uurimistulemuste põhjal, et kuigi tüdrukute tulemused olid kõikide komponentide puhul paremad kui poiste omad (tabelid 4 ja 5), ei ole need erinevused suurtest valimitest tingitud väikese mõju suuruse (alla $0,2)$ tõttu sisuliselt märkimisväärsed.

\section{Arutelu ja järeldused}

Uuritud neljast bioloogia-alase kirjaoskuse komponendist on just kontekstiga seotud aineteadmiste reprodutseerimine kõige kõrgemal (ca 80\%) saavutustasemel, seda nii 10. kui ka 11. klassi õpilastel. Tulemus on oluline seetõttu, et teadmised on bioloogia-alase kirjaoskuse üks määravaid komponente ning ilma nendeta pole võimalik bioloogia-alast kirjaoskust arendada, nagu seda näeb ette gümnaasiumi riiklik õppekava (2011). Kõikide bioloogia-alase kirjaoskuse komponentide (loova mõtlemise oskuse, probleemide lahendamise oskuse, otsuste vastuvõtmise ja põhjendamise oskuse) käsitlemisel on rõhutatud aineteadmisi, mis on heal saavutustasemel 
bioloogia-alase kirjaoskuse väljakujunemise eeldus (Cliff \& Curtin, 2000; Gürses et al., 2007; Heller, 2007; Mumford et al., 2010; Şenocak et al., 2007). Nagu Sadler ja Zeidler (2005) rõhutavad, on heade aineteadmistega õpilastel palju kergem lahendada probleeme ja vastu võtta otsuseid. Ainult aineteadmiste omandamist ei pea aga ühiskonna huvigrupid piisavaks ja sellega ei saa piirduda ei loodushariduses tervikuna ega ka bioloogiahariduses (Laius et al., 2015a). Bioloogiateadmiste kõrge saavutustase näitab, et eesti koolis on endiselt põhirõhk aineteadmiste omandamisel.

Teine bioloogia-alase kirjaoskuse komponent, mille saavutustaset siinses uurimuses mõõdeti, on probleemide lahendamise oskus. See lisab bioloogia-alasele kirjaoskusele uue mõõtme - teadmiste rakendamise oskuse probleemide lahendamisel. Teadmiste osa probleemide lahendamisel on rõhutatud ka mitmes varasemas (Gürses et al., 2007; Şenocak et al., 2007) uurimuses, sest see aitab õpilasi paremini ette valmistada reaalse elu olukordadeks, kus nad peavad olema valmis probleeme jooksvalt ja kiiresti lahendama. Probleemide lahendamise oskust kui elus eduka hakkamasaamise olulist osa on rõhutatud ka teistes rahvusvahelistes uurimustes (Brown et al., 2005; Bybee \& Fuchs, 2006; European Commission, 2010; Fensham, 2004; Holbrook, 2014; Ravenscroft et al., 2012).

Selle komponendi saavutustase on praeguse uurimuse kohaselt keskmine ( $c a 65 \%)$ ning seda nii 10. kui ka 11. klassis. Peale keskmisele saavutustasemele kuuluvate probleemilahendusülesannete osutus üks ainealaselt keerukam probleemilahendusülesanne (ülesanne 5) vastavaks madalale saavutustasemele (44\%). Selline tulemus pole paraku see, mida õpilastelt tulevikus oodatakse, sest Eesti tööandjad rõhutavad, et nad ootavad eelkõige just teadmiste rakendamise oskust probleemide lahendamisel (Laius et al., 2015a; Laius et al., 2016; Post, Rannikmäe, \& Holbrook, 2011).

Kolmas bioloogia-alase kirjaoskuse taseme komponent, mille saavutustaset siinses uurimuses hinnati, oli otsuste tegemine ja põhjendamine. Tulemused näitavad, et kui eelmainitud kahe komponendi saavutustase oli kõrge ja keskmine, siis kolmas komponent jäi madalale saavutustasemele (alla 50\%). Steffen ja Hößle (2016) märgivad, et kuigi otsuste tegemine bioloogiatunnis ei asenda reaalse elu olukorda, annab see noortele inimestele hea võimaluse praktiseerida või imiteerida tulevikus ette tulla võivaid situatsioone. Ka selline ettevalmistus on parem kui mitte midagi, sest nii eri huvigrupid, gümnaasiumi riiklik õppekava kui ka ühiskonna ootused osutavad (Greiff \& Neubert, 2014; Gümnaasiumi riiklik õppekava, 2011; Laius et al., 2015a; Laius et al., 2016; Post et al., 2011), et heal tasemel otsuste tegemise oskus annab eelise tööjõuturul ja tagab eduka tuleviku, karjääri või paremini sujuva igapäevaelu. Probleem on aga selles, et õpilased 
on küll varustatud heal tasemel aineteadmistega, mida illustreerivad väga ilmekalt ka head tulemused rahvusvahelistes testides, nt PISA 2015 (PISA 2015 Eesti tulemused, 2016), kuid järgmise olulise sammuni ehk teadmiste rakendamiseni õpilased, sh 11. klassi õpilased, gümnaasiumiõppe jooksul ei jõua.

Neljas, ühtlasi viimane uuritud komponent, loodusteadusliku loova mõtlemise oskus, eeldas õpilastelt teadmiste rakendamist uues ja võõras situatsioonis, nii et nad pidid leidma võimalikult palju eri aspektidest lähtuvaid lahendusi. Loovat mõtlemist mõõtvad ülesanded osutusid õpilastele keeruliseks nii 10. kui ka 11. klassis, samuti jättis väga suur hulk õpilasi ( $c a$ 19\%) nendele kui mitteharjumuspärastele ülesannetele vastamata. Just loova mõtlemise arendamine annab õpilastele võimaluse leida ebatavalistele või harjumatutele probleemidele uusi lahendusi nii, et protsessi oleks kaasatud teadmiste rakendamine ja otsuste tegemine (Basadur et al., 2014; Csikszentmihalyi, 1996; Heller, 2007; Mumford et al., 2010; Sternberg et al., 2002). Loodusteadusliku loova mõtlemise komponendi madal saavutustase annab tunnistust asjaolust, et õpilaste loodusteadusliku loova mõtlemise arendamine pole olnud kuigi edukas ning loovat mõtlemist nõudvates olukordades, mida muu hulgas rõhutasid ka eri huvigrupid (Laius et al., 2015a; Laius et al., 2016; Post et al., 2011), jäävad õpilased selle testi tulemusi arvestades kindlasti raskustesse.

Kuna eespool analüüsitud bioloogia-alase kirjaoskuse komponendid, mis eeldavad teadmiste rakendamist, on oma olemuselt universaalsed, siis võib eeldada, et neid on eesti koolis üldiselt veel vähe arendatud, seda ilmselt seetõttu, et tänapäevaseid õpetamisviise ei vallata või ei kasutata koolis veel piisavalt. Samas on varasematest uurimustest (Soobard \& Rannikmäe, 2014) selgunud, et 10. ja 11. klassi õpilased ise hindavad enda oskusi otsuste tegemisel ja nende põhjendamisel keskmisest paremaks. Vastuolu õpilaste enesehinnangu ja testi tegelike tulemuste vahel viitab sellele, et bioloogiatundides ei ole seda tüüpi oskusi hinnatud, mistõttu puudub õpilastel adekvaatne tagasiside oma oskuste kohta.

Loodusainete tulemuste analüüsimisel on alati tähelepanu pööratud sugudevahelistele erinevustele, sest valdavaks rahvusvaheliseks tendentsiks on poiste suurem motivatsioon ja seetõttu ka paremad tulemused (PISA 2006, 2015). Praegune uuring näitab, et gümnaasiumiastmes eristuvad poiste ja tüdrukute võrdluses mõlemas klassis tüdrukute tulemused: 10. klassi tüdrukud lahendasid nii kõrge kui ka keskmise saavutustasemega ülesandeid ning 11. klassi tüdrukud kõrge ja madala saavutustasemega ülesandeid poistega võrreldes statistiliselt olulisel määral paremini, kuid suurest valimist tingituna ei saa neid erinevusi väikese mõju suuruse 
(Coheni $d<0,2)$ tõttu koolikontekstis sisuliselt oluliseks pidada. See on kooskõlas PISA 2015 tulemustega, mille alusel on soolised erinevused loodusainete keskmistes tulemustes matemaatika ja lugemisoskusega võrreldes väiksemad ning viimasel ajal pigem kahanevad, sõltudes ühiskonnast. Seega saavad neid mõjutada nii vanemad, õpetajad kui ka huvigrupid. Erinevalt paljudest teistest riikidest valitseb samasugune tendents (tüdrukute mõningane paremus) ka Soomes (OECD, 2016).

Olgugi et õppekava on orienteeritud pigem loodusteaduslike teadmiste rakendamisele, näitavad uuringu tulemused, et see uue kompetentsipõhise õppekava eesmärk ei ole veel realiseerunud üldhariduskooli gümnaasiumiastme loodusainete tundides (Laius et al., 2016). Õpilasteni ei ole jõudnud arusaam, et ühiskond ootab oskuste rakendamist, sest nende arvates on senini olnud koolis kõige olulisem aineteadmiste omandamine ja nad peavad seda ka hästi realiseerituks.

Head teadmiste rakendamise oskust peavad teadmistest olulisemaks ka Eesti huvigruppide esindajad, sest vähesed aineteadmised küll piiravad probleemide lahendamist ja põhjendatud otsuste tegemist nii isiklikus kui ka tööelus (Laius et al., 2016; Post et al., 2011), kuid kui koolis on põhirõhk aine kohta faktide omandamisel, siis ilma oskuseta neid rakendada ei vasta niisuguste õpilaste bioloogia-alase kirjaoskuse tase tänapäeva ühiskonna ja tööturu vajadustele.

\section{Kokkuvõte}

Uurimuse eesmärk oli välja selgitada, millised on gümnaasiumiõpilaste bioloogia-alase kirjaoskuse kognitiivsete komponentide - kontekstiga seotud aineteadmiste ning probleemide lahendamise, otsuse tegemise ja põhjendamise ning loova mõtlemise oskuse - saavutustasemed. Selleks kasutati kaheksast kontekstipõhisest ülesandest koosnevat testi laktoositalumatuse kohta. Testi tegid 44 Eesti gümnaasiumi 10. ja 11. klassi 2048 õpilast (1096 naissoost ja 952 meessoost õpilast).

Eelnevast kirjanduse analüüsist selgus, et gümnaasiumilõpetajalt oodatakse oluliselt rohkem loova mõtlemise, probleemide lahendamise ja otsuste tegemise oskuse omandamist, kui tegelik olukord seda koolis võimaldab.

Tulemuste kokkuvõtteks võib väita, et nii 10. kui ka 11. klassi õpilastel on head aineteadmiste tulemused (I komponent - kõrge saavutustase), mille saavutamiseks pidid nad reprodutseerima üksnes aineteadmisi. Kui I komponent on õpilastele koolist tuttav, siis järgmised komponendid (II-IV), mis eeldavad probleemide lahendamist, otsuste tegemist ja põhjendamist või loodusteadusliku loova mõtlemise (mõõdetuna voolavuse 
aspektist) rakendamist, valmistavad neile raskusi, kuna nende oskuste saavutustasemed olid testi tulemuste põhjal keskmised või madalad.

Ülesannete sisuline analüüs näitas, et kõige kergemaks osutusid kaks küsimust, mis nõudsid aineteadmiste reprodutseerimist laktoositalumatuse kontekstis. Kõik keskmisel saavutustasemel ülesanded olid ainega seotud probleemilahendusülesanded. Õpilastele osutusid keeruliseks loodusteaduslikku loovat mõtlemist eeldavad ülesanded (IV komponent), mille saavutustase oli madal. Otsuse tegemist ja põhjendamist vajavad ülesanded (III komponent) olid samuti madalal saavutustasemel. Kõige keerulisem ehk madalaima saavutustasemega oli ülesanne, mille lahendamiseks tuli kanda keemia- ja bioloogiaalaseid teadmisi ning oskusi üle uude konteksti (III komponent).

Kuigi kõiki teadmisi, mis on vajalikud ülesannete edukaks lahendamiseks, on erinevates põhikooli ja gümnaasiumi õpikutes käsitletud (lisad 1 ja 2), ei piisanud üksnes teadmiste olemasolust, et neid uues kontekstis rakendada. Seega võib arvata, et gümnaasiumi riiklikus õppekavas (2011) eeldatavad õpitulemused (eelkõige probleemi lahendamine ja otsuse tegemine) pole 10. ja 11. klassis realiseerunud ning teadmiste juurdekasv pole oskuste kujunemisele märkimisväärselt kaasa aidanud. Madala saavutustasemega olid pigem need ülesanded, mida ilmselt koolis iga päev hindamisel ei kasutata (loodusteaduslik loov mõtlemine ning otsuse tegemine ja põhjendamine).

Uuringu tulemused tõestavad paraku, et bioloogia-alase kirjaoskuse komponendid (probleemide lahendamise, otsuste tegemise ja põhjendamise ning loodusteadusliku loova mõtlemise oskus) on madalal saavutustasemel nii 10. kui ka 11. klassi õpilastel, kes on küll kaks aastat gümnaasiumis loodusaineid õppinud, kuid see ei kajastu nende bioloogia-alase kirjaoskuse komponentide mõõdetud tulemustes.

Tulemustes esinesid küll kõikides ülesannetes erinevused tüdrukute kasuks, kuid märkimisväärset sugudevahelist lõhet siiski Eesti gümnaasiumiõpilaste bioloogia-alase kirjaoskuse komponentides ei olnud.

\section{Soovitused}

Korraldatud uuringu väärtus seisneb selles, et see annab tõenduspõhise ülevaate Eesti bioloogia-alase kirjaoskuse kognitiivsetest komponentidest ja võimaldab teha olulisi järeldusi Eesti gümnaasiumiõpilaste nende oskuste kohta, mida ootavad gümnaasiumilõpetajatelt Eesti ühiskonna huvigrupid ja mis on õpitulemustena fikseeritud ka 2011. aastal rakendunud õppekavas, kuid mis praeguse uuringu tulemuste kohaselt ei ole veel täiel määral 
realiseerunud. Põhjusteks võib olla hariduses toimuvate muutuste inertsus, mis osutab koolis õpetavate õpetajate täienduskoolituse vajadusele, aga ka õpetajakoolitusse tulevate noorte bioloogiaõpetajate vähesusele.

Olukorra parandamiseks on uurimistulemuste põhjal soovitatav pakkuda loodusainete õpetajatele täienduskoolituse kursusi, mille ülesehitamisel tuleks keskenduda eelkõige selliste pedagoogiliste meetodite tutvustamisele, mis võimaldaksid arendada õpetajate oskusi kasutada õppetöös ülesandeid, mis eeldavad loovat probleemide lahendamist ning otsuste tegemist ja põhjendamist. Sellise kursuse planeerimisel soovitavad autorid kasutada rühmatööd, kus loodusainete õpetajad arendavad oma suhtlemisja koostööoskusi, töötades 4-5-liikmelistes rühmades ning koostades igapäevaeluga seotud loodusteaduslikke kontekstipõhiseid õppematerjale, mis aitaksid õpilastel ainetundides õpitud teadmisi ja oskusi rakendada uutes olukordades. Lisaks tuleb populariseerida gümnaasiumi loodusteaduste õpetajate elukutset, et kõrgkooli tuleksid õppima andekamad gümnaasiumilõpetajad, kellel on teadmisi, oskusi ja motivatsiooni muuta koolibioloogia tunnid tänapäeva nõuetele vastavaks.

\section{Tänusõnad}

Artikli autorid tänavad kõiki uuringus osalenud õpilasi ja õpetajaid. Uurimus on valminud projekti LoTeGüm raames, mida toetas SA Archimedes grandiga NLOLO09580.

\section{Kasutatud kirjandus}

Basadur, M., Gelade, G., \& Basadur, T. (2014). Creative problem-solving process styles, cognitive work demands, and organizational adaptability. The Journal of Applied Behavioral Science, 50(1), 80-115. https://doi.org/10.1177/0021886313508433

Batey, M., Chamorro-Premuzic, T., \& Furnham, A. (2009). Intelligence and personality as predictors of divergent thinking: The role of general, fluid and crystallised intelligence. Thinking Skills and Creativity, 4(1), 60-69. https://doi.org/10.1016/j.tsc.2009.01.002

Beier, Y. (2014). The collaborative advantage. The rewards of a collaborative culture are significant, but so is the effort to get there. Communication World, 33(1), 22-25.

Brown, B. A., Reveles, J. M., \& Kelly, G. J. (2005). Scientific literacy and discursive identity: A theoretical framework for understanding science learning. Science Education, 89(5), 779-802. https://doi.org/10.1002/sce.20069 
Bybee, R. W., \& Fuchs, B. (2006). Preparing the 21st century workforce: A new reform in science and technology education. Journal of Research in Science Teaching, 43(4), 349-352. https://doi.org/10.1002/tea.20147

Cliff, W. H., \& Curtin, L. N. (2000). The directed case method: Teaching concept and process in a content-rich course. Journal of College Science Teaching, 30(1), 64-66.

Cohen, J. (1988). Statistical power analysis for the behavioral sciences (2nd ed.). Hillsdale: Lawrence Erlbaum Associates.

Csikszentmihalyi, M. (1996). Creativity: Flow and the psychology of discovery and invention. New York: Harper Collins.

Demastes, S., \& Wandersee, J. H. (1992). Biological literacy in a college biology classroom. BioScience, 42(1), 63-65. https://doi.org/10.2307/1311631

Demir, S., \& Şahin, F. (2014). Assessment of open-ended questions directed to prospective science teachers in terms of scientific creativity. Procedia-Social and Behavioral Sciences, 152, 692-697. https://doi.org/10.1016/j.sbspro.2014.09.264

Eastwood, J. L., Sadler, T. D., Sherwood, R. D., \& Schlegel, W. M. (2013). Students' participation in an interdisciplinary, socio-scientific issues based undergraduate human biology major and their understanding of scientific inquiry. Research in Science Education, 43(3), 1051-1078. https://doi.org/10.1007/s11165-012-9298-x

European Commission (2010). Special Eurobarometer 340: Science and technology. Retrieved from http://ec.europa.eu/public_opinion/archives/ebs/ebs_340_en.pdf.

Fensham, P. J. (2004). Increasing the relevance of science and technology education for all students in the 21st century. Science Education International, 15(1), 7-26.

Furnham, A., Batey, M., Booth, T. W., Patel, V., \& Lozinskaya, D. (2011). Individual difference predictors of creativity in Art and Science. Thinking Skills and Creativity, 6(2), 114-121. https://doi.org/10.1016/j.tsc.2011.01.006

Greiff, S., \& Neubert, J. C. (2014). On the relation of complex problem solving, personality, fluid intelligence, and academic achievement. Learning and Individual Differences, 36, 37-48. https://doi.org/10.1016/j.lindif.2014.08.003

Griffin, P., McGaw, B., \& Care, E. (Eds.) (2012). Assessment and teaching of 21st century skills. Dordrecht: Springer.

Gümnaasiumi riiklik õppekava (2011). Riigi Teataja I, 29.08.2014, 21. Külastatud aadressil https://www.riigiteataja.ee/akt/129082014021.

Gürses, A., Açıkyıldız, M., Doğar, Ç., \& Sözbilir, M. (2007). An investigation into the effectiveness of problem-based learning at physical chemistry laboratory. Research in Science \& Technological Education, 25(1), 99-113.

https://doi.org/10.1080/02635140601053641

Happonen, P., Holopainen, M., Sariola, H., Sotkas, P., Tenhunen, A., TihtarinenUlmanen, M., ... \& Sepp, T. (2013). Bioloogia õpik gümnaasiumile, IV kursus. Evolutsioon. Ökoloogia. Keskkonnakaitse. Tallinn: Avita.

Heller, K. A. (2007). Scientific ability and creativity. High Ability Studies, 18(2), 209234. https://doi.org/10.1080/13598130701709541

Holbrook, J. (2014). A context-based approach to science teaching. Journal of Baltic Science Education, 13(2), 152-154.

Ida-Tallinna Keskhaigla (2009). Laktoositalumatus. Külastatud aadressil http://www.itk.ee/upload/files/Patsiendi-infomaterjal/ITK528_Laktoositalumatus.pdf. 
Johnson, B., \& Christensen, L. (2000). Educational research: Quantitative and qualitative approaches. Boston: Allyn \& Bacon.

Kahan, D. M., Peters, E., Wittlin, M., Slovic, P., Ouellette, L. L., Braman, D., \& Mandel, G. (2012). The polarizing impact of science literacy and numeracy on perceived climate change risks. Nature Climate Change, 2, 732-735. https://doi.org/10.1038/nclimate1547

Kim, M. K., Roh, I. S., \& Cho, M. K. (2016). Creativity of gifted students in an integrated math-science instruction. Thinking Skills and Creativity, 19, 38-48. https://doi.org/10.1016/j.tsc.2015.07.004

Kokassaar, U., Martin, M., \& Relve, K. (2013). Bioloogia ópik 9. klassile, II osa. Tallinn: Avita.

Kokassaar, U., \& Relve, K. (2013). Bioloogia õpik 9. klassile, I osa. Tallinn: Avita.

Kübarsepp, J. (2006). Üldhariduskool kõrgkooli pilguga. Haridus, 9-10, 33-36.

Laius, A., Post, A., \& Rannikmäe, M. (2015a). Identifying Estonian stakeholder views as the bases for designing science teachers' in-service course which support promotion of competence based curriculum goals. Science Education International, 26(1), 62-71.

Laius, A., Post, A., \& Rannikmäe, M. (2016). Determining support of Estonian stakeholders for a new competence-based science education curriculum. International Journal of Education and Information Technologies, 10, 14-24.

Laius, A., Valdmann, A., \& Rannikmäe, M. (2015b). A comparison of transferable skills development in Estonian school biology at gymnasium level. Procedia Social and Behavioral Sciences, 177, 320-324.

https://doi.org/10.1016/j.sbspro.2015.02.349

Lavonen, J., Gedrovics, J., Byman, R., Meisalo, V., Juuti, K., \& Uitto, A. (2008). Students' motivational orientations and career choice in science and technology: A comparative investigation in Finland and Latvia. Journal of Baltic Science Education, 7(2), 86-102.

Lember, M., Torniainen, S., Kull, M., Saadla, P., Rajasalu, T., Lepiksoo, M., \& Järvelä, I. (2007). Pärilik primaarne hüpolaktaasia - genotüübid ja nende seos piimatalumatusega. Eesti Arst, 86(6), 383-386.

Lile, R., \& Bran, C. (2014). The assessment of learning outcomes. Procedia - Social and Behavioral Sciences, 163, 125-131. https://doi.org/10.1016/j.sbspro.2014.12.297

Loewenthal, K. M. (2004). An introduction to psychological tests and scales (2nd ed.). Hove: Psychology Press.

Majandus- ja Kommunikatsiooniministeerium (2013). Eesti ettevõtluse kasvustrateegia 2014-2020. Külastatud aadressil http://kasvustrateegia.mkm.ee/.

Martin, M., Toom, M., \& Kokassaar, U. (2002). Bioloogia põhikoolile II. Tallinn: Avita.

Mumford, M. D., Hester, K. S., \& Robledo, I. C. (2010). Scientific creativity: Idealism versus pragmatism. Gifted and Talented International, 25(1), 59-64.

https://doi.org/10.1080/15332276.2010.11673550

OECD (2014). PISA 2012 results: Creative problem solving: Student's skills in tackling real-life problems (Vol. 5). Paris: OECD.

OECD (2016). PISA 2015 results: Excellence and equity in education (Vol. 1). Paris: OECD Publishing. 
Papadouris, N., \& Constantinou, C. P. (2010). Approaches employed by sixth-graders to compare rival solutions in socio-scientific decision-making tasks. Learning and Instruction, 20(3), 225-238. https://doi.org/10.1016/j.learninstruc.2009.02.022

PISA 2006 Eesti tulemused (2008). Tartu: Haridus- ja Teadusministeerium. Külastatud aadressil https://www.hm.ee/sites/default/files/pisa_2006_esti_tulemused.pdf.

PISA 2015 Eesti tulemused: Eesti 15-aastaste õpilaste teadmised ja oskused matemaatikas, funktsionaalses lugemises ja loodusteadustes (2016). Tallinn: Innove. Külastatud aadressil https://www.hm.ee/sites/default/files/pisa_2015_final_veebivaatamiseks_0.pdf.

Post, A., Rannikmäe, M., \& Holbrook, J. (2011). Stakeholder views on attributes of scientific literacy important for future citizens and employees - a Delphi study. Science Education International, 22(3), 202-217.

Quinn, H., Schweingruber, H., \& Keller, T. (Eds.) (2011). A framework for K-12 science education: Practices, crosscutting concepts, and core ideas. Washington: Committee on Conceptual Framework for the New K-12 Science Education Standards; National Research Council.

Ravenscroft, A., Lindstaedt, S., Kloos, C. D., \& Hernández-Leo, D. (Eds.) (2012). 21st century learning for 21st century skills. 7th European Conference on Technology Enhanced Learning, EC-TEL2012 Saarbrücken, Germany, September 2012, Proceedings. https://doi.org/10.1007/978-3-642-33263-0

Relve, K., Kirk, A., Tuvikene, A., Pappel, P., Hain, E., Mägi, E., ... \& Kollist, Ü. (2011). Bioloogia 7. klassile. Tallinn: Avita.

Relve, K., Kokassaar, U., Martin, M., Vanatoa, A., Rammul, Ü., Rammul, I., ... \& Kollist, Ü. (2012). Bioloogia õpik 8. klassile, II osa. Tallinn: Avita.

Sadler, T. D., \& Zeidler, D. L. (2005). The significance of content knowledge for informal reasoning regarding socioscientific issues: Applying genetics knowledge to genetic engineering issues. Science Education, 89(1), 71-93.

https://doi.org/10.1002/sce.20023

Sarapuu, T. (2003). Bioloogia gümnaasiumile. I osa. Tartu: Eesti Loodusfoto.

Sarapuu, T., Viikmaa, M., \& Puura, I. (2006). Bioloogia gümnaasiumile. II osa 4. kursus. Tartu: Eesti Loodusfoto.

Schleicher, A. (2014). A plan for education. OECD Forum. Retrieved from http://www.oecd.org/education/a-plan-for-education.htm.

Şenocak, E., Taşkesenligil, Y., \& Sözbilir, M. (2007). A study on teaching gases to prospective primary science teachers through problem-based learning. Research in Science Education, 37(3), 279-290. https://doi.org/10.1007/s11165-006-9026-5

Soobard, R., \& Rannikmäe, M. (2014). Upper secondary students' self-perceptions of both their competence in problem solving, decision making and reasoning within science subjects and their future careers. Journal of Baltic Science Education, 13(4), 544-558.

Steffen, B., \& Hößle, C. (2016). Assessing students' performances in decision-making: Coping strategies of biology teachers. Journal of Biological Education, 51(1), 44-51. https://doi.org/10.1080/00219266.2016.1156012

Sternberg, R. J., Kaufman, J. C., \& Pretz, J. E. (2002). The creativity conundrum: A propulsion model of kinds of creative contributions. New York: Psychology Press. 
Tehnunen, A., Hain, E., Venäläinen, J., Tihtarinen-Ulmanen, M., Holopainen, M., Sotkas, P., ... \& Tsaro, K. (2012). Bioloogia gümnaasiumile, II. Tallinn: Avita.

Teichmann, M., \& Kübarsepp, J. (2008). Students' preparation for, and coping with, tertiary level science and engineering education. In J. Holbrook, M. Rannikmäe, P. Reiska, \& P. Ilsley (Eds.), The need for a paradigm shift in science education for post-Soviet societies (pp. 184-198). Frankfurt am Main: Peter Lang.

Tenson, T., Kaldalu, N., Tehnunen, A., Hain, E., Venäläinen, J., Tihtarinen-Ulmanen, M., ... \& Happonen, P. (2013). Bioloogia gümnaasiumile, III. Tallinn: Avita.

Tervise Arengu Instituut (2016). Laktoositalumatus. Külastatud aadressil http://toitumine.ee/toitumine-ja-haigused/toidutalumatus/laktoositalumatus.

Toom, M., Tedersoo, L., \& Relve, K. (2012). Bioloogia 8. klassile. 1. osa. Tallinn: Avita.

Tsakanikos, E., \& Claridge, G. (2005). Less words, more words: Psychometric schizotypy and verbal fluency. Personality and Individual Differences, 39(4), 705-713. https://doi.org/10.1016/j.paid.2005.02.019

Uno, G. E., \& Bybee, R. W. (1994). Understanding the dimensions of biological literacy. BioScience, 44(8), 553-557. https://doi.org/10.2307/1312283

Usta, E., \& Akkanat, Ç. (2015). Investigating scientific creativity level of seventh grade students. Procedia - Social and Behavioral Sciences, 191, 1408-1415. https://doi.org/10.1016/j.sbspro.2015.04.643

Venäläinen, J., Tenhunen, A., Hain, E., Tihtarinen-Ulmanen, M., Sotkas, P., Happonen, P., \& Holopainen, M. (2012). Bioloogia õpik gümnaasiumile, 1. kursus. Bioloogia kui teadus. Organismid. Rakuõpetus. Tallinn: Avita. 
Lisa 1. 2011. aasta põhikooli ja gümnaasiumi riikliku õppekava järgi koostatud bioloogiaõpikute sisu vastavus bioloogia-alase testi küsimustele

\begin{tabular}{|c|c|c|c|c|c|c|c|c|c|}
\hline \multirow{2}{*}{$\begin{array}{l}\text { KLASS JA } \\
\text { ÕPIK }\end{array}$} & \multirow[t]{2}{*}{ SISU } & \multicolumn{8}{|c|}{ ÜLESANDED } \\
\hline & & 1 & 2 & 3 & 4 & 5 & 6 & 7 & 8 \\
\hline $\begin{array}{l}\text { 7. klass } \\
\text { (Relve } \\
\text { et al., 2011) }\end{array}$ & $\begin{array}{l}\text { Piim on vastsündinute põhitoit, mis } \\
\text { sisaldab kõiki eluks vajalikke toitaineid } \\
\text { (rasvu, valke, süsivesikuid jt aineid). }\end{array}$ & 0 & 0 & 0 & $\mathbf{x}$ & 0 & 0 & 0 & 0 \\
\hline \multirow[t]{2}{*}{$\begin{array}{l}\text { 8. klass } \\
\text { (Toom, } \\
\text { Tedersoo, \& } \\
\text { Relve, 2012; } \\
\text { Relve et al., } \\
\text { 2012) }\end{array}$} & $\begin{array}{l}\text { Eestis on müügil organismile kasulike } \\
\text { piimhappebakteritega rikastatud } \\
\text { toiduaineid: biojogurt, -keefir, -jogurti- } \\
\text { jäätis. Need toiduained sisaldavad } \\
\text { elavaid baktereid, kes soodustavad } \\
\text { seedetegevust. }\end{array}$ & 0 & $\mathbf{x}$ & 0 & 0 & 0 & 0 & 0 & 0 \\
\hline & $\begin{array}{l}\text { Piimhappebakterite abil valmistatakse } \\
\text { jogurtit, hapukoort, hapupiima jt } \\
\text { hapendatud piimatooteid. }\end{array}$ & 0 & $\mathbf{x}$ & 0 & 0 & 0 & 0 & 0 & 0 \\
\hline $\begin{array}{l}\text { 9. klass } \\
\text { (Kokassaar \& } \\
\text { Relve, 2013; } \\
\text { Kokassaar, } \\
\text { Martin, \& } \\
\text { Relve, 2013) }\end{array}$ & $\begin{array}{l}\text { Ensüüme leidub kõikides kudedes, kus } \\
\text { nad muudavad reaktsioonide kiirust, } \\
\text { tavaliselt kiirendavad neid. Iga ensüüm } \\
\text { osaleb vaid üht tüüpi keemilises } \\
\text { reaktsioonis. }\end{array}$ & 0 & 0 & 0 & $\mathbf{x}$ & 0 & 0 & 0 & 0 \\
\hline \multirow{4}{*}{$\begin{array}{l}\text { Gümnaa- } \\
\text { siumi } \\
\text { I kursus } \\
\text { (Veneläinen } \\
\text { et al., 2012) }\end{array}$} & $\begin{array}{l}\text { Laktoos ehk piimasuhkur on } \\
\text { kaheosaline liitsuhkur, mida } \\
\text { leidub peamiselt piimas. }\end{array}$ & 0 & 0 & 0 & 0 & $\mathbf{x}$ & 0 & 0 & 0 \\
\hline & $\begin{array}{l}\text { Laktoos ehk piimasuhkur esineb } \\
\text { kõikide imetajate piimas. Lehmapiimas } \\
\text { on laktoosi kuni 5\%. }\end{array}$ & 0 & 0 & 0 & 0 & $\mathbf{x}$ & 0 & 0 & 0 \\
\hline & $\begin{array}{l}\text { Näiteks tekib laktoositalumatus siis, } \\
\text { kui peensoole rakkudes ei valmi } \\
\text { laktoosi ehk piimasuhkrut lõhustavaid } \\
\text { ensüüme või valmib neid liiga vähe. } \\
\text { Piimasuhkru lõhustumist peensooles } \\
\text { ei toimu, mistõttu liigub see hoopis } \\
\text { jämesoolde. Jämesooles lagundavad } \\
\text { piimasuhkru bakterid ning lõpp- } \\
\text { produktideks on piimhape, vesi ja } \\
\text { gaasid. Tagajärjeks on mitmesugused } \\
\text { vaevused, maoturse ja kõhuvalu. }\end{array}$ & $\mathbf{x}$ & 0 & 0 & 0 & $\mathbf{x}$ & 0 & 0 & $\mathbf{X}$ \\
\hline & $\begin{array}{l}\text { Bakterite kasutamine biotehnoloogias } \\
\text { ja toiduainete valmistamisel. }\end{array}$ & 0 & $\mathbf{x}$ & 0 & 0 & 0 & 0 & 0 & $\mathbf{x}$ \\
\hline
\end{tabular}




\begin{tabular}{|c|c|c|c|c|c|c|c|c|c|}
\hline \multirow{2}{*}{$\begin{array}{l}\text { KLASS JA } \\
\text { ÕPIK }\end{array}$} & \multirow[t]{2}{*}{ SISU } & \multicolumn{8}{|c|}{ ÜLESANDED } \\
\hline & & 1 & 2 & 3 & 4 & 5 & 6 & 7 & 8 \\
\hline \multirow{4}{*}{$\begin{array}{l}\text { Gümnaa- } \\
\text { siumi } \\
\text { II kursus } \\
\text { (Tehnunen } \\
\text { et al., 2012) }\end{array}$} & $\begin{array}{l}\text { Piimhappekäärimist rakendatakse } \\
\text { toiduainetööstuses. Näiteks kasu- } \\
\text { tatakse jogurti valmistamisel baktereid, } \\
\text { mille mõjul hakkab piimhape käärima. }\end{array}$ & 0 & $\mathbf{x}$ & 0 & 0 & 0 & 0 & 0 & $\mathbf{x}$ \\
\hline & $\begin{array}{l}\text { Eestis müüdavad organismile kasulike } \\
\text { piimhappebakteritega rikastatud } \\
\text { toiduained avaldavad inimeste } \\
\text { organismile soodsat mõju, } \\
\text { soodustades seedetegevust. }\end{array}$ & 0 & $\mathbf{x}$ & 0 & 0 & 0 & 0 & 0 & $\mathbf{x}$ \\
\hline & $\begin{array}{l}\text { Piima joomist võimaldab mutatsioon: } \\
\text { enamik täiskasvanud imetajaid ei saa } \\
\text { piima juua, sest nende organism ei } \\
\text { tooda täiskasvanueas piimasuhkru } \\
\text { laktoosi lagundamiseks vajalikku } \\
\text { ensüümi laktaasi. Siinkohal on } \\
\text { erandiks inimene. Ilmselt oli piim } \\
\text { toiduallikana täiskasvanueas } \\
\text { oluline just põhja pool elavatele } \\
\text { inimpopulatsioonidele. }\end{array}$ & 0 & 0 & 0 & $\mathbf{x}$ & 0 & $\mathbf{x}$ & 0 & $\mathbf{x}$ \\
\hline & $\begin{array}{l}\text { Kui viljastunud munarakk jaguneb } \\
\text { embrüonaalse arengu algusjärgus } \\
\text { kaheks, on tulemuseks ühemuna- } \\
\text { kaksikud. Kuna nende genotüüp on } \\
\text { sama, tulenevad nende erinevused } \\
\text { ainult keskkonnateguritest. }\end{array}$ & 0 & 0 & 0 & 0 & 0 & 0 & $\mathbf{x}$ & 0 \\
\hline \multirow{4}{*}{$\begin{array}{l}\text { Gümnaa- } \\
\text { siumi } \\
\text { III kursus } \\
\text { (Tenson } \\
\text { et al., 2013) }\end{array}$} & $\begin{array}{l}\text { Ühemunarakukaksikud on geneetiliselt } \\
\text { identsed: neil on ühesugune genoom. } \\
\text { Nad on välimuselt väga sarnased. }\end{array}$ & 0 & 0 & 0 & 0 & 0 & 0 & $\mathbf{x}$ & 0 \\
\hline & $\begin{array}{l}\text { Erimunakaksikud tekivad kahe } \\
\text { munaraku samaaegse viljastamise } \\
\text { tulemusena ja on geneetiliselt sama } \\
\text { sarnased kui vennad või õed ikka. }\end{array}$ & 0 & 0 & 0 & 0 & 0 & 0 & $\mathrm{x}$ & 0 \\
\hline & $\begin{array}{l}\text { Bakterites toodetud ensüüme } \\
\text { kasutatakse paljude toiduainete } \\
\text { valmistamisel. Vähese laktoosi- } \\
\text { sisaldusega toiduainete saamiseks } \\
\text { lisatakse neile ensüümi laktaasi, mis } \\
\text { lõhustab piimas sisalduvat laktoosi. }\end{array}$ & 0 & $\mathbf{x}$ & 0 & 0 & 0 & 0 & 0 & 0 \\
\hline & $\begin{array}{l}\text { Piimhappebakterid kääritavad piima- } \\
\text { suhkru ehk laktoosi piimhappeks } \\
\text { ning mõjutavad niiviisi toidu maitset, } \\
\text { struktuuri ja säilivust. }\end{array}$ & 0 & $\mathbf{x}$ & $\mathbf{x}$ & 0 & 0 & 0 & 0 & 0 \\
\hline
\end{tabular}




\begin{tabular}{|c|c|c|c|c|c|c|c|c|c|}
\hline \multirow{2}{*}{$\begin{array}{l}\text { KLASS JA } \\
\text { ÕPIK }\end{array}$} & \multirow[t]{2}{*}{ SISU } & \multicolumn{8}{|c|}{ ÜLESANDED } \\
\hline & & 1 & 2 & 3 & 4 & 5 & 6 & 7 & 8 \\
\hline \multirow[t]{2}{*}{$\begin{array}{l}\text { Gümnaa- } \\
\text { siumi } \\
\text { IV kursus } \\
\text { (Happonen } \\
\text { et al., 2013) }\end{array}$} & $\begin{array}{l}\text { Enamik täiskasvanud imetajaid piima } \\
\text { juua ei saa, sest nende organism ei } \\
\text { tooda täiskasvanueas piimasuhkru } \\
\text { laktoosi lagundamiseks vajalikku } \\
\text { ensüümi laktaasi. }\end{array}$ & $\mathbf{x}$ & $\mathbf{x}$ & $\mathbf{x}$ & 0 & 0 & 0 & 0 & 0 \\
\hline & $\begin{array}{l}\text { Umbes } 10000 \text { aastat tagasi toimunud } \\
\text { geneetilise mutatsiooni tõttu on } \\
\text { võimalik piima juua ka täiskasvanueas. } \\
\text { Mutatsiooni lai levik näitab, et see } \\
\text { oli äärmiselt vajalik. Eelkõige on see } \\
\text { mutatsioon levinud eurooplaste seas. }\end{array}$ & $\mathbf{x}$ & $\mathbf{x}$ & $\mathbf{x}$ & $\mathbf{x}$ & 0 & 0 & 0 & 0 \\
\hline
\end{tabular}

${ }^{\star} 0$ - õpik ei sisalda testiga seonduvat aineinfot.

${ }^{\star *} \mathrm{X}$ - õpik sisaldab testiga seonduvat aineinfot. 
Lisa 2. 2002. aasta põhikooli ja gümnaasiumi riikliku õppekava järgi koostatud bioloogiaõpikute sisu vastavus laktoositalumatuse testi küsimustele

\begin{tabular}{|c|c|c|c|c|c|c|c|c|c|}
\hline \multirow{2}{*}{$\begin{array}{l}\text { KLASS JA } \\
\text { ÕPIK }\end{array}$} & \multirow[t]{2}{*}{ SISU } & \multicolumn{8}{|c|}{ ÜLESANDED } \\
\hline & & 1 & 2 & 3 & 4 & 5 & 6 & 7 & 8 \\
\hline \multirow{2}{*}{$\begin{array}{l}\text { Põhikooli } \\
\text { 2. osa } \\
\text { (Martin, } \\
\text { Toom, \& } \\
\text { Kokassaar, } \\
2002 \text { ) }\end{array}$} & $\begin{array}{l}\text { Piimhappebakterite abil valmistatakse } \\
\text { jogurtit, hapukoort, hapupiima jt } \\
\text { hapendatud piimatooteid. }\end{array}$ & 0 & $\mathbf{x}$ & 0 & 0 & 0 & 0 & 0 & 0 \\
\hline & $\begin{array}{l}\text { Müüdavad probiootilised toiduained } \\
\text { sisaldavad elavaid baktereid } \\
\text { ja toimivad soodsalt inimese } \\
\text { organismile: soodustavad seede- } \\
\text { tegevust, kiirendavad toitainete } \\
\text { imendumist, vähendavad kahjulike } \\
\text { bakterite arvukust soolestikus, } \\
\text { tõhustavad organismi kaitsesüsteeme. }\end{array}$ & 0 & 0 & 0 & 0 & 0 & 0 & 0 & $\mathrm{x}$ \\
\hline $\begin{array}{l}\text { Gümnaasiumi } \\
\text { 1. osa } \\
\text { (Sarapuu, } \\
\text { 2003) }\end{array}$ & $\begin{array}{l}\text { Ühemuna- ja erimunakaksikute } \\
\text { embrüoloogia ja erinevused } \\
\text { tekkemehhanismis ning geno- } \\
\text { tüübiline identsus ja erinevus } \\
\text { fenoloogilistes tunnustes. }\end{array}$ & 0 & 0 & 0 & 0 & 0 & 0 & $\mathbf{x}$ & 0 \\
\hline $\begin{array}{l}\text { Gümnaasiumi } \\
\text { 4. osa } \\
\text { (Sarapuu, } \\
\text { Viikmaa, \& } \\
\text { Puura, 2006) }\end{array}$ & $\begin{array}{l}\text { Ühemuna- ja erimunakaksikute } \\
\text { embrüoloogia ja erinevused } \\
\text { tekkemehhanismis ning avaldumine } \\
\text { fenoloogilistes tunnustes. }\end{array}$ & 0 & 0 & 0 & 0 & 0 & 0 & $\mathbf{X}$ & 0 \\
\hline
\end{tabular}

* 0 - õpik ei sisalda testiga seonduvat aineinfot.

${ }^{* *} \mathrm{x}$ - õpik sisaldab testiga seonduvat aineinfot. 


\title{
Assessing the biological literacy cognitive components of 10th and 11th grade students
}

\author{
Aveliis Post $^{\mathrm{a} 1}$, Helin Semilarski ${ }^{\mathrm{a}}$, Anne Laius ${ }^{\mathrm{a}}$ \\ ${ }^{a}$ Centre for Science Education, University of Tartu
}

\section{Summary}

According to the PISA 2006 and 2015 surveys, 15-year-old Estonian students are among the top level of scientific literacy worldwide (PISA 2015 Eesti tulemused, 2016). However, when these students enter university, they fail to show a high level of scientific literacy, and there is little or no impact made on the Estonian economy by these gymnasium graduates (Kübarsepp, 2006; Teichmann \& Kübarsepp, 2008; Majandus- ja Kommunikatsiooniministeerium, 2013). A study investigating students' scientific literacy is needed at gymnasium level to discover the reasons why this situation exists.

A future society can be expected to face the huge problem of how to educate young people capable of being able to sustain levels of scientific literacy when solving problems, or making everyday life decisions. Future students must be prepared to work in areas that, as yet, do not exist and work with tools that have yet to be developed (Greiff \& Neubert, 2014; Schleicher, 2014). Besides a need for people to be able to use their scientific knowledge when solving problems, and make decisions both at work and at home, there is also a need for developing innovative and creative thinking skills. Linked to this is the need to acquire the ability to adjust and adapt to new situations, people and challenges (Brown et al., 2005; Bybee \& Fuchs, 2006; European Commission, 2010; Fensham, 2004; Holbrook, 2014; Ravenscroft et al., 2012).

Stakeholders, including employers, scientists, educators, etc. (Laius et al., 2015a), see scientific literacy, within the workforce, as playing a major role for the future of Estonian society and these skills need to be developed and nurtured at gymnasium level. The current research focuses on the state of the current biological education. Given that all the scientific subjects (physics, chemistry, biology and earth sciences) have conjoined scientific practices and cross cutting concepts and are in line with the New Generation Science Standards (Quinn et al., 2011), each one of them

Centre for Science Education, University of Tartu, Vanemuise 46, 51014 Tartu, Estonia; aveliis.post@ut.ee 
maintains specific disciplinary core ideas or subject knowledge. When considering the above-mentioned situation, the term biological literacy is coined in place of scientific literacy to stress a focus on teaching and learning within biology lessons.

In striving to determine the biological literacy levels of students, this study focuses on a context of lactose intolerance. It devises an instrument for measuring biological literacy within 4 cognitive components, of which only the biological content knowledge is specific to biology and the other 3 cognitive components (problem solving, decision making and reasoning and creative thinking skills, measured as divergent thinking fluency) are mutual to both biological literacy and scientific literacy.

Lactose intolerance, which affects some $25 \%$ of the Estonian population, is chosen as a context, because the topic has gained much attention in the country and public awareness of the context has risen among the population. The number of lactose free dairy products has also increased in recent years (Ida-Tallinna Keskhaigla, 2009; Lember et al., 2007; Tervise Arengu Instituut, 2016).

The goal of biology education according to the new Estonian National Curriculum (2011) is to enhance biological literacy so that by the end of their compulsory education students are expected to be able to apply biological knowledge to new contexts. The aim of this study is to use a context-based instrument to measure 10th and 11th grade students' biological literacy through 4 cognitive components: biological knowledge; problem solving; decision making and reasoning, and the fluency aspect of the scientific creativity (afterwards simply referred to as scientific creativity). The study also aimed to determine differences in achievement levels between certain factors, such as the gender and age of the students. The preliminary results, based on descriptive statistics, are as presented at the international conference - Global Conference on Contemporary Issues in Education (Laius et al., 2015b).

These four cognitive components of biological literacy were selected for assessment to meet the needs of the Estonian labour market according to the opinions of Estonian stakeholders, which were revealed from a study conducted by Laius and co-authors (Laius et al., 2016). The National Gymnasium Curriculum and school biology textbooks were analysed to ensure that the prerequisite biological background could be expected to enable students to effectively complete the biological literacy test tasks in the context of lactose intolerance.

For a more in-depth analysis of this research, the following 3 research questions are posed: 
1. What is the status of gymnasium students' biological literacy measured within a scenario of lactose intolerance, determined from the following four cognitive components: biological knowledge, problem-solving, decision-making and reasoning and creativity skills?

2. What are the differences in biological literacy among 10th and 11th grade students associated with the following four cognitive components: biological knowledge, problem-solving, decision-making and reasoning, and creativity skills?

3. Do gender differences occur in biological literacy based on the following four cognitive components (biological knowledge, problem-solving, decision-making and reasoning and creativity skills)?

The sample for this study, taken from 44 Estonian gymnasiums, consisted of 1116 grade 10 students (598 girls and 518 boys) and 932 grade 11 students (498 girls and 434 boys), amounting to a total of 2048 students (1096 female and 952 male students).

The validity of the instrument was determined by piloting the test with 35,10 th grade students and using three independent experts (two science education researchers and one experienced biology teacher who validated the relevance of the tasks in the test). The reliability measure for internal coherence (Cronbach $\alpha=0.63$ ) of the instrument indicated that the instrument is sufficiently robust (Loewenthal, 2004) considering the low number of tasks (8) used in the instrument.

The reliability of the study was achieved by using a representative sample, while content reliability was provided by coding the test results from two different biology teachers, with another two experts who approved the coding criteria. Cronbach a was used to measure the internal consistency of the biological literacy test. A Chi-square test was used to determine the significance of the sampling distribution of the achievement level groups (for all three groups $p=0.000$ ).

The data was analysed using the programme IBM SPSS 22. In addition to descriptive statistics, the non-parametric tests of Mann-Whitney and Kruskall-Wallis were used to measure the significance between investigated samples. The effect size (Cohen's $d$ ) was used to indicate the magnitude of the difference between groups (Cohen, 1988).

Students' answers were coded using a 4-point scale. The mean results were expressed as a percentage of the maximum result and then grouped, based on achievement rates at three hierarchical levels (high achievement level 70\% and above; medium achievement level 51-69\%; low achievement level $50 \%$ and below). These levels were chosen, based on the assessment criteria of the Estonian Curriculum. 
The results show that the tasks measuring biological content knowledge in the lactose intolerance context (high achievement level) were answered better than the other cognitive components, in line with the results from PISA 2015 (PISA 2015 Eesti tulemused, 2016). This indicates that students' biological knowledge is at a mean achievement level of $78 \%$ and this cognitive component of biological literacy has developed more than the other cognitive components during gymnasium studies.

Results of the tasks addressing problem-solving skills showed that students had a mean achievement level of $66 \%$, which is less than the level of expectation expressed by Estonian stakeholders (Laius et al., 2015a; Laius et al., 2016).

Decision-making and reasoning skills were at a low achievement level, meaning that students' had a poor appreciation of how to make effective decisions and reason them. Good decision making and reasoning skills are highly valued competencies that Estonian stakeholders expect from graduating students (Laius et al., 2015a; Laius et al., 2016).

Scientific creativity skills which were assessed through the aspect of fluency (evaluated by the number of different responses from students) were also at a low achievement level. This refers to the case that students are not used to finding solutions to unfamiliar tasks that presume generating different ideas at their lessons.

The lowest achievement rate (44\%) was obtained by students solving a complicated scientific problem (task 5) that presumed a profound understanding of the process of digestion and enzymatic decay. This indicates that the students are not able to transform their biology and chemistry knowledge, thus solving a problem in new situation.

The comparative results of the 10th and 11th grade students indicate that the measured cognitive components of biological literacy do not differ significantly between the 10th and 11th grade students during the two years of gymnasium studies. Girls from 10th and 11th grade perform statistically significantly better than boys (in both grades) based on four of the tasks, but the effect size (Cohen's $d<0.2$ ) shows that due to the large sample the difference is not meaningful.

In conclusion, the results indicate that different cognitive components of biological literacy can be measured by creating a context-based test such as that based on lactose intolerance. The comparison between 10th and 11th grade do not show significant difference in the results. Despite an extra year of studies in 11th grade, the results in comparison with their earlier 10th grade results do not show a significant increase during 2 years of gymnasium biology studies. 
The results of this study provide a foundation for devising a further action plan for developing gymnasium students' cognitive components of biological literacy. The authors of the study suggest the development of a model for a teacher in-service training course that concentrates on the four cognitive components addressed in the study, with a special focus on creative problem-solving, decision-making and reasoning skills all components having low levels of achievement.

Keywords: biological literacy, context-based assessment, lactose intolerance, gymnasium students 